Savunma Bilimleri Dergisi

The Journal of Defense Sciences

Kasım/Nov 2017, Cilt/Volume 16, Say1/Issue 2.

ISSN (Bas111) : 1303-6831 ISSN (Online): 2148-1776

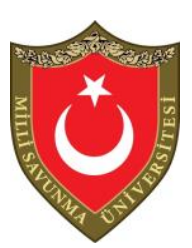

\title{
Uluslararası Hukuk Çerçevesinden Arktik Güvenliği Politikalarının Analizi: Rusya ve ABD Örneği
}

\author{
Burcu GÜÇLÜ AKPINAR ${ }^{1}$
}

\begin{abstract}
$\ddot{O} z$
Son yıllarda artan küresel ısinma ile beraber kuzey kutbunu kaplayan buz tabakası daha fazla erimeye başlamıştır. Eriyen tabaka deniz alanını daha kullanılabilir bir duruma getirmiş ve deniz tabanında yer alan hidrokarbonlara erişim daha kolay hâle gelmiştir. Bu iklimsel değişime bă̆ll olarak ülkelerin bu alan ile ilgili politikaları da ciddi anlamda değişime uğramıştır. Öyle ki, dünyanın belki de en zorlu yaşam koşullarına ev sahipliği yapan Arktik bölgesi ekonomik ve siyasal kazanımların odak noktası haline gelmiştir. Bölgenin uluslararası statüsü ve egemenlik alanları konusunda tartışmalar baş göstermiştir. Böylece Arktik O’na komşu olan ülkeler arasında çıkarların çatıştığ bir alana dönüşmüşürr. Bu durum Rusya ve ABD'nin rekabet koşullarının değişmesine de neden olmuştur. Ayrıca Arktik, küresel ölçekte yaratmış olduğu etkileri ile birlikte düşünüldükçe, giderek sorunlu bir bölgeye dönüşmektedir. Bu sorunların çözümü için ise, uluslararası hukukun esas alınması ihtiyacı doğmaktadır. $B u$ çalışma, Rusya ve ABD’nin Uluslararası Hukuk çerçevesinden Arktik Bölgesi’ne yönelik güvenlik politikalarını analiz ederek, bu politikaların iki devlet üzerinde ne gibi siyasi, ekonomik ve sosyo-kültürel etkiler ortaya çıkardığını tartışmaktadır.
\end{abstract}

Anahtar Kelimeler: Arktik Bölgesi, Uluslararası Hukuk, Güvenlik Politikalarl, Rusya, ABD.

${ }^{1}$ Uludağ Üniversitesi, Sosyal Bilimler Enstitüsü, Uluslararası İlişkiler Bölümü, Doktora Öğrencisi, i.gucluburcu@gmail.com 


\title{
Analysis of Arctic Security Policies from the Perspective of International Law: The Cases of Russia and the US
}

\begin{abstract}
In recent years, with the rise of global warming, ice layer on the North pole has begun to melt with increasing rates. This melting layer has made the marine area more useable and the access to hydrocarbons in the seabed has become easier. Depending on this climatic change, the politics of the countries in this area have also changed significantly. The Arctic region, which hosts perhaps the most challenging living conditions of the world, has become a focal point of the economic and political gains. Therewith, discussions on the international status and sovereignty areas of the region have begun among countries which have been neighbor to this region. Thus, Arctic has turned into an area of conflicting interests among the neighboring countries. This has also caused Russia and the US to challenge the competition conditions. Arctic is also becoming a problematic region on the global scale. In order to solve these problems, it is necessary to refer to the International Law. This study analyzes the security policies of the Arctic regions of Russia and United States from the framework of International Law and discusses the political, economic and socio-cultural implications of these policies on the two states.
\end{abstract} Russia, USA.

Keywords: Arctic Region, International Law, Security Policies,

\section{Giriş}

Arktik Bölgesi'nin sahip olduğu uluslararası önem iklimsel değişim sonucunda artmıştır. Bölgedeki 1S1 artışı buzulların erimesine neden olmakta, bu da deniz tabanındaki doğal kaynaklara erişime kolaylık sağlamaktadır. Bu doğal kaynakların çıkarılması ve işletilmesi konusunda yaşanabilecek uyuşmazlıklar ise kıyıdaş ülkelerin üzerinde durdukları temel güvenlik problemleri içinde yer almaktadır. Bu problemlerin çözümü ve bölgede güvenliğin tesis edilmesindeki en önemli husus ise, ülkelerin uluslararası hukuk kurallarını temel alan politikalar icra ediyor olmalarıdır.

Arktik'e kıyıdaş olan ülkelerin bu bölge üzerindeki egemenlik iddiaları ve buna bağlı olarak geliştirdikleri siyasi, askeri, ekonomik ve sosyo-kültürel politikalar da genel anlamda bir hukuki altyapı üzerinde 
Uluslararası Hukuk Çerçevesinden Arktik Güvenliği Politikalarının Analizi:

Rusya ve ABD Örneği

yükselmektedir. Hukuk, ülkelerin güvenliğini ve öz savunmalarını sağlarken, çıkar temelli hareket edilmesinin önüne geçerek faaliyetlerini hakkaniyet temelinde icra etmelerini salık vermektedir. Arktik politikaları için ise bu vazgeçilmez bir dayanak oluşturmaktadır. Özellikle Arktik'e sınırı bulunan ülkelerin bu durumun bilincinde olarak Uluslararası Hukuk vasıtasıyla çıkarlarını koruma altına aldıkları anlaşılmaktadır.

$\mathrm{Bu}$ çalışma Arktik Bölgesi'nin sahip olduğu benzersiz özelliklerin küresel anlamda yaratmış olduğu öneme vurgu yaparak, bölgenin Uluslararası Hukuk kapsamında nasıl değerlendirilmesi gerektiğini ve akabinde Arktik'teki Rusya/ABD rekabetini ele almaktadır. Uluslararası Hukuk çerçevesinden Rusya ve ABD'nin Arktik politikalarının da sırasıyla incelendiği bu çalışmada, iki ülkenin Arktik Güvenliği üzerinde yaratmış oldukları olumlu ve olumsuz etkiler tartışılmaktadır.

\section{Arktik Bölgesinin Genel Özellikleri ve Küresel Çaptaki Önemi}

Arktik Bölgesi tam olarak Arktik çember (Arctic Circle) içindeki buzla kaplı olan Kuzey Kutbu ve Arktik Okyanusu'nu da içine alan bölge olarak tanımlanmaktadır (https://www.nwf.org). Arktik çember, sahip olduğu 33 milyon $\mathrm{km}^{2}$ alanı ile Afrika ya da Asya'dan daha geniş bir bölgeyi kaplar (http://ec.europa.eu')

Arktik Okyanusu, geniş ve sığ kıta levhaları ile sınırlandırılmış olup sualtı dağ sıraları tarafından ayrılmış iki ana havzayı içermektedir. Bu dağ sıralarına Lomonosov sirtları denir ki; bunlar, Kuzey Kutbu'na yakın bir çizgi boyunca uzanan Yeni Sibirya Takımadaları ile Grönland'ın Kuzeyinde birleşir (http://ec.europa.eu).

Arktik bölgesi daha yeryüzüne çıkartılmamış petrol kaynaklarının \%13'üne, doğal gazın \%30'una, sıvı doğal gazın \%20'sine ev sahipliği yapmaktadır. Bu kaynakların \%84'ünün açık denizlerde olduğu tahmin edilmektedir (Macalister, 2011). Ham maddelerin bu bölgedeki bolluğundan dolayı jeologlar Arktik bölgesine "Ali Baba'nın Mağarası" ismini vermişlerdir (Bittner, 2016: 1).

Arktik Bölgesi, Arktik çember esas alınarak ifade edilecek olunursa; Rusya, Kanada, Danimarka, ABD, Norveç, İsveç, Finlandiya ve İzlanda topraklarının bir kısmını kapsar. Bu bölge geniş Arktik olarak kabul edilir. Araştırmalara ve uyuşmazlıklara konu olan Arktik bölgesi ise daha çok Arktik Okyanusu kıyılarıdır. Arktik Okyanusu'na kıyısı bulunan ülkeler ise; Rusya, Kanada, ABD, Danimarka ve Norveç’tir. 
Arktik bölgesi dünya çapında sahip olduğu zorlu koşulları ile bilinmektedir. Arktik, üzerinde yaşamın sürdürülebilmesinin çok güç olduğu bir iklime sahiptir. Bu iklimde yaşanan değişimler son yıllarda bilim insanlarının bir hayli dikkatini çekmiştir. Önümüzdeki yıllarda küresel 1sınma ile birlikte dünya ikliminde öngörülen bir 1sı artışının (öngörülen +1 ya da +2 derecelik) Arktik üzerinde de ciddi etkiler doğuracağı kesindir. Aslında Arktik’teki bir değişimin tüm dünya için de bir değişim anlamına geldiğini söylemek yanlış olmayacaktır. Çünkü dünyamızın karşı karşıya kaldığı küresel 1sınma sorunu bu bölgenin iklimi üzerinde de ciddi etkiler yaratmaya başlamıştır. İklimsel değişimler bölgenin buz kütleleri ile kaplı yüzeyinde erimelerin gözlenmesine neden olmuş, bu erime beraberinde ileride yaşanabilecek bir takım sorunları da gün yüzüne çıkarmaya başlamıştır. Örneğin, bir sorun olarak görülen olası karbon salınımı ile ilgili yapılan çalışmalar dikkat çekicidir. Bu çalışmalara göre, eğer ki kutuplarda sürekli donmuş hâlde bulunan toprak (Permafrost) 1sınma ve erime süreçleri içinde çözünmeye başlarsa, uzun süre toprak içinde depolanan karbonun doğaya salınımı gerçekleşmeye başlayacak, sonuçta dünya yıllarca uzayan bir sera etkisine maruz kalacaktır (https://insideclimatenews.org). Yoğun sera etkisinin tüm yaşamı tehdit ettiği açık bir husustur.

Diğer yandan, Arktik bölgesindeki erime, bölgenin önemli biyo kaynakları üzerinde araştırma yapmayı biraz olsun kolaylaştırmıştır. Örneğin, son y1llarda Aerobiyolojinin bir alan olarak gelişimi ile birlikte Arktik bölgesinde yaşayan mikroplar ve bunların atmosferdeki dağılımları, birbirleri ile etkileşimleri ve evrimlerinin ekolojik düzeydeki yansımaları, bu mikropların aşırı sıcaklıklara, UV maruziyetlerine ve yetersiz besin düzeylerine karşı dayanıklılık göstermeleri bilimsel açıdan incelenmeye başlanmıştır (Cuthbertson vd., 2017). Bölgedeki yoğun erimenin tüm gezegenimiz üzerinde yaratacağı olası riskler ile sağlayacağı faydaların birçok alanda analiz edilmekte olduğu anlaşılmaktadır. Özellikle, Okyanus kıyılarındaki yerleşim alanları ile iç denizlerde deniz seviyesi altında bulunan kıyı şehirleri bu durumdan ilk etkilenecek alanlar olarak kabul edilmektedir. $\mathrm{Bu}$ alanların yoğun nüfus miktarları göz önünde bulundurulduğunda tehlikenin ne derece büyük olduğu açıkça anlaşılmaktadır.

Diğer yandan farklı alanlardaki teknolojik gelişmeler de bizim bu bölge üzerinde daha fazla bilgi sahibi olmamıza yardımcı olmaktadır. Örneğin; uydu sistemleri ve uzay alanındaki çalışmalar bölgenin haritası üzerinde ciddi katkılar sunmaktadır. Hâlihazırda bu bölge ile ilgili 
Uluslararası Hukuk Çerçevesinden Arktik Güvenliği Politikalarının Analizi:

Rusya ve ABD Örneği

çalışmalar yapan NASA [National Aeronautics and Space Administration (Ulusal Havacilık ve Uzay Dairesi-ABD)] ve GFZ [Geo Forschungs Zentrum, (Yerbilimleri Araştırma Merkezi-Almanya)] ortaklığında icra edilen GRACE-FO misyonu bulunmaktadir (https://directory.eoportal.org).

$\mathrm{Bu}$ yeni misyon GRACE 1 ve 2 uydularının sunmuş olduğu hizmetlerin birer devamı niteliğinde görülerek hazırlanmıştır. GRACEFO'nun program yöneticisi Frank Webb'in belirttiğine göre; bu uyduların sağladıkları veriler ile Arktik ve Antarktika'daki buzul kütlelerindeki kayıplar ile Güney Amerika, Avusturya ve Asya'da kuraklaşma seviyelerinde belli birtakım eğilimler bulunduğu gözlemlenmiştir. Bunlar, gezegenin iklimimizde olan değişimlere karşı nasıl cevap verdiğinin ana göstergeleridir (Buis, 2016). Açıç̧a belirtmek gerekirse, Arktik'te yaşanan en ufak bir değişim Dünya'nın diğer bölgelerindeki canlı yaşam üzerinde ciddi etkiler birakmaktadır.

Tüm bu bilimsel veriler 1şığında erimenin ileri tarihlerde artacağı tespit edilmiştir. Bu durumun yaratacağı jeopolitik ve jeostratejik sonuçlar bölgeye kıyısı dahi olmayan ülkelerin politik gündemlerinde yer almaya başlanmıştır. Yukarıda belirtilenlerin dışında daha birçok bilimsel alandaki çalışmalara ev sahipliği yapan Arktik Bölgesi, Uluslararası İlişkiler disiplininde de üzerinde dikkatle çalışılması gereken bir alan olarak düşünülmüş̧ür. Çünkü bu bölgede yaşanan iklim temelli değişimlerin, tüm dünyanın karşı karșıya kalacağı doğal afetlerden ekonomik sorunlara, uluslararası göçlerden siyasal uyuşmazlıklara kadar daha sayamadığımız birçok sorunu da beraberinde getireceği tahmin edilmektedir. $\mathrm{Bu}$ yüzden ülkeler dış politika ve güvenlik konularında yeni tehdit unsurlarıyla baş edebilmek için önlemler almak, politikalar üretmek zorunda kalacaktır.

21.yy'da yaşanan çok yönlü değişimler ve etkileşimler, üzerinde yaşadığımız bu gezegeni artık daha savunmasız bir alan haline getirmektedir. Bu durum bizi birçok çalışma alanının ancak birlikte çözüm üretebileceği sorunlar yumağı ile baş başa bırakmaktadır. $\mathrm{Bu}$ sorunlar içerisinde Arktik Bölgesi, küresel 1sınmanın çok etkili olduğu ve mevcut buz tabakalarının erimesine bağlı olarak fiziki coğrafyasının da değişmeye başladığı bir bölge olarak karşımıza çıkmaktadır. Astill'in belirttiği gibi Arktik, 1951 yılından beri yaklaşık olarak küresel ortalamanın iki katı kadar 1sınmaktadır (http://www.economist.com). Isınmaya bağlı olarak incelen ve çözünen buz tabakası altında yer alan zenginliklerin ortaya çıkması başta bölgeye kıyısı bulunan ülkeler olmak üzere tüm dünyanın da dikkatini üzerine çekmiştir. Yine 1sınmaya bağlı olarak, kıtalar arası taşımacılık 
faaliyetleri ile deniz ticaret yollarının tekrar gözden geçirilme ihtiyacı ortaya çıkmıştır. Arktik Bölgesinde yaşanan bu gibi değişimler yeni firsatlarla birlikte yeni sorun alanlarının ortaya çıkmasına olanak tanımıştır. Bu durum bölgenin statüsünün belirlenmesinin yanı sıra bölgeye komşu devletlerin egemenlik haklarına ilişkin hususların da uluslararası hukuk kapsamında analiz edilmesi ihtiyacını tetiklemiştir.

\section{Uluslararası Hukuk Kapsamında Arktik ve ABD/Rusya Rekabeti}

17.yy'ın başlarında İngiliz yazar Selden, açık denizlerdeki tüm alanların oralarda gücünü uygulayabilen devletlerin hâkimiyetleri ya da egemenliklerinin kontrolü altında olduğunu savunurken, Hollandalı diplomat ve hukukçu Grotius, denizlerin özgürlüğü argümanını ortaya koymuştur (Gardiner, 2003: 392-393). Bu tarihsel savunma ancak yüz y1llar sonra bir kanun hâline gelebilmiştir.

Deniz hukuku önemli ölçüde İkinci Dünya Savaşı'ndan sonra gelişim göstermiştir. 1950'lerde denizlerde gözlenen hak iddiaları ve uyuşmazlık sayısındaki dramatik artış, balıkçılık yöntemlerindeki değişimlerle birlikte teknolojik ilerlemeler, hukukun açıklığa kavuşturulması için bir ihtiyacı ortaya çıkartmıştır (Hillier, 1999: 183). Deniz Hukuku böylece 1958 ve 1960 yıllarında düzenlenen 1. ve 2. Cenevre Deniz Hukuku Konferansları sonucunda 4 sözleşme olarak ortaya çıkmıştır.

Bunlar:

- $\quad$ Karasuları ve Bitişik Bölge Sözleşmesi,

- $\quad$ Açık Denizler Sözleşmesi,

- Kita Sahanlığı Sözleşmesi,

- $\quad$ Açık Denizlerde Balıkçılık ve Canlı Kaynakların Korunması sözleşmesidir (Harris, 2004: 381).

Bunlara ek olarak Pazarcı, Uyuşmazlıkların Zorunlu Çözümüne İlişkin İhtiyari Protokol'ü de vurgulamıştır (Pazarcı, 2010:255). Tüm bu sözleşmeler ve protokol denizler ile ilgili düzenlemeyi yapan modern deniz hukukunun temeli olarak kabul edilir. Günümüz koşullarında denizlerdeki hukuki meseleleri yorumlamamıza yardımcı olan Birleşmiş Milletler Deniz Hukuku Sözleşmesi (BMDHS), ancak 1973 yilında New York'ta toplanılarak dokuz sene sonra yani 1982'de Deniz Hukuku anayasası hâline 
Uluslararası Hukuk Çerçevesinden Arktik Güvenliği Politikalarının Analizi:

Rusya ve ABD Örneği

gelmiştir (http://www.un.org). 1982 Sözleşmesi 320 Madde ve 9 EK'i ihtiva eder. Sözleşme 130 olumlu, 4 ret, 17 çekimser oy ile kabul edilmiştir. Gerekli 60 onay sayısının alınmasından 12 ay sonra 16 Kasım 1994'te yürürlüğe girmiştir (Shaw, 2008: 555-556).

Sözleşme birçok devletin deniz alanlarında yaşadıkları uyuşmazlıkların çözüme kavuşturulması için esas kabul edilmektedir. Ancak sözleşmeyi onaylayan ülkeler arasında karasuları, münhasır ekonomik bölgeler, açık denizler gibi alanlarda yaşanan anlaşmazlıkların çözülmesinde tarafların iyi niyet sergilemeleri sayesinde belirli bir başarı sağlanırken, üzerinde hala ortak bir anlaşma bulunmayan ve statüsü tartışmalı olan bölgeler için aynı şeyi söylemek mümkün değildir. $\mathrm{Bu}$ bölgelerden biri de Arktik bölgesidir.

Kutup bölgelerinin hukuksal durumu konusunda bütün devletlerce kabul edilmiş yapılageliş (teamül) ya da andlaşma kurallarından söz etmek güçtür. İlgili devletler, kendi çıkarları açısından ölçütler ileri sürmektedirler: Keşif, ülkeye bitişiklik, ülkenin uzantısı, komşu alanlar kuramı gibi görüşlere dayanan hak savları görülmektedir (Meray, 1977: 130).

İşte Arktik bölgesindeki Uluslararası Hukuk rejimi de, yüzyıllar boyunca hiç kimseye ait olmayan toprak üzerinde (terra nullius) egemenlik kazanımına ilişkin uluslararası hukuk pratikleri ve doktrinleriyle birlikte şekil almıştır (Kovalev, 2013: 28).

Başlangıçta bölgeye kıyıdaș ülkelerin Arktik havzasında yer alan kıta sahanlığı sınırları konusunda aralarında resmi bir mutabakat bulunmamakta ve bu mutabakatı sağlayacak herhangi bir uluslararası gücün varlığından da bahsedilememekteydi. Ancak bu noktada Arktik bölgesinin tüm sorunları ile ilgilenmek için kurulmuş olan Arktik Konseyi taraflara ortak bir çözüm platformu sunmaya başladı (http://www.arctic-council.org). Arktik Konseyi ayrica, bir dizi yerel halk organizasyonunun da daimi katılımcı statüsü verildiği bir alan olarak, ulus aşırı meselelerle de ilgilenmeye başladı. Özellikle yerel halkların korunması adına birçok çalışmaya imza atmıştır. Konseyde hâlihazırda altı yerel halk organizasyonunun temsiliyeti bulunmaktadır. Bunlar: Innuit Kutupçevresi Konseyi (Innuit Circumpolar Council), Sami Konseyi (Saami Council), Rusya Kuzey Yerli Halkları Birliği [Russian Assosiation of Indigenous Peoples of the North (RAIPON)], Aleut Uluslararası Birliği [Aleut International Association (AIA)], Arktik Athabaska Konseyi (Arctic Athabaskan Council) ve Gwich'in Uluslararası Konseyi (Gwich'in Council 
International) olarak adlandırılmaktadır (https://accelfellowship.wordpress. com ).

Tüm bu yapılanmalar, sorunların uluslararası hukuk kuralları çerçevesinde çözülmesi gerekliliğini yinelememize neden olmaktadır. Bu bağlamda 1982 yılında deklare edilen BMDHS, özellikle Arktik Okyanusu'ndaki sorunların çözülmesi için büyük önem taşımaktadır. Arktik'e kıyısı olan ülkelerden biri olan ABD'nin bu anlaşmayı imzalamasına rağmen onaylamamış olması diğer Arktik ülkeleri ile birlikte hareket etmesini zorlaştırmaktadır. Buna rağmen ABD birçok konuda bu anlaşmaya sadık kaldığını ifade etmektedir. Mevcut sorunların çözüm temeli olarak BMDHS'nin esas alınmasını veto etmediği gözlenmektedir. ABD Arktik ülkelerinin bölgeyle ilgili olan tüm öneri ve çekincelerinin yine bu ülkeler arasında görüşülmesi gerektiği inancını korumaktadır. Bunun için zaman zaman diğer Arktik ülkeleri ile bir araya geldiği gözlenmiştir.

28 Mayıs 2008 tarihinde de Arktik Okyanusuna sınırı olan 5 kıyı devleti (ABD, Rusya, Kanada, Norveç, Danimarka) Greenland'ın Ilulissat bölgesinde Arktik Okyanusu Konferansında siyasal düzeyde bir toplantı icra etmişlerdir (http://www.wikiwand.com). Ilulissat Deklerasyonu olarak anılan bu toplantıda temel yasal çerçevenin Uluslararası Deniz Hukuku olarak kabul edildiği gözlenmiş, taraflar Arktik Okyanusu'nu yönetecek yeni "geniş kapsamlı bir uluslararası yasal rejimin" geliştirilmesine ihtiyaç duymadıklarını bildirmișlerdir (http://www.oceanlaw.org). Geniș kapsamlı uluslararası yasal rejime verilebilecek en güzel örnek Antarktika'da uygulanandır. Bu bağlamda Arktik, Antarktika'da uygulanan rejimden ayrı tutulmaktadir.

Arktik Bölgesine kıyısı bulunan devletlerin bu bölge için çok taraflı bir uluslararası yapıyı istememelerindeki belki de en büyük neden bu bölgedeki ekonomik çıkarlarının maksimum seviyede korunmasını sağlamaktır. Duyck'un da belirttiği gibi “... bir avuç kıyı ülkesi Uluslararası Hukuk temelinde meşru olarak, Arktik kaynaklarının birçoğu üzerinde egemenlik iddiasında bulunabilirken, uluslararası toplum Antarktika'da herhangi bir egemenlik iddiasını evrensel olarak kabul etmemektedir" (2011:1). Bölge açıkça bu beş Arktik ülkesinin egemenlik alanına terk edilmiş gibi gözükmektedir. Temel yasal dayanaklarının da BMDHS olması bu ülkelere büyük avantajlar sağlamaktadır.

Halen Danimarka, Norveç, Kanada ve Rusya, BMDHS'ni Arktik Okyanusu ve deniz yatağındaki yasal taleplerini dile getirmekte kullanmaktadırlar. Anlaşmaya taraf olmayarak ABD bu önemli inisiyatifte 
Uluslararası Hukuk Çerçevesinden Arktik Güvenliği Politikalarının Analizi:

Rusya ve ABD Örneği

diğer ulusların avantajına olan resmi konumdan yoksun bulunmaktadır (Sorokin, 2015). Özellikle kıta sahanlığı, münhasır ekonomik bölgeler, uluslararası deniz yatağı ve açık deniz alanlarında düzenlemelerin yapılmasına olanak sağlayan BMDHS hükümleri sözleşmeye taraf olan ülkelerin bu konulardaki iddialarını güçlendirmek adına bir dizi fayda sunmaktadır.

Rusya'nın kıta sahanlığı konusunda yapmış olduğu bilimsel çalışmalar da buna örnek gösterilebilir. Kıta sahanlığının şart ve koşulları BMDHS'de açıkça belirtilmiştir. Ayrıca, Köni'nin de belirttiği gibi 1982 Deniz Hukuku Sözleşmesinin 76. maddesi ve eklerine göre bazı koşulları yerine getirmek suretiyle kıta sahanlığını genişletmek mümkün olabilmektedir (2016, s. 29). BMDHS'nin Ek-2 madde 4'üne göre: “Bir kıyı devleti 76. Maddeye uygun olarak kıta sahanlığının 200 deniz mili dışındaki sınırlarını belirleme niyetinde bulunduğu zaman, bu sınırların detaylarını mümkün olan en kısa zamanda, her durumda sözleşmenin yürürlüğe girmesini müteakip 10 sene içinde, iddiasını destekleyici bilimsel ve teknik veriyle birlikte komisyona sunmakla yükümlüdür..." (http://www.un.org/depts/los/convention_agreements/texts/unclos/unclos_e. pdf) (s.146).

Anlaşma açıkça sahildar ülkelerin hak taleplerini dikkate almaktadır. Gerekli şartların sağlanmasına müteakip hakkın yasal yollar kullanılarak elde edilmesini salık vermektedir. Bu haklardan olan egemenlik hakkının ancak hukukun üstünlüğü çerçevesinde elde edilebilecek olması da dikkat çekicidir.

Arktik'e kıyısı olan devletlerden herhangi birisinin kıta sahanlığının genişlemesi durumunda egemenlik alanı da genişleyecektir. Fakat bunun için kıta sahanlığı alanının belirlenmesi gerekmektedir. Arktik’te kıta sahanlıklarının genişletilebilmesi için ise okyanus tabanının bilimsel olarak incelenmesi şartı aranmaktadır. Ayrıca ihtilaflı alanlar için yapılacak bilimsel çalışmaların BM nezdinde ve hukuk kuralları çerçevesinde takip ediliyor olması beklenmektedir. Arktik'te kendi kıta sahanlığı ile ilgili bilimsel araştırmalar yapan Rusya'nın çalışmaları bu anlamda dikkat çekicidir.

2001 y1lında BM'e başvuran Rusya, Arktik Okyanusu'ndaki kıta sahanlığının sınırlarının belirlenmesini talep eden ilk Arktik ülkesidir (Aliferova, 2012: 7). Bu girişimi ile birlikte Rusya, bölgedeki uyuşmazlıkları BMDHS çerçevesinde çözme niyetinde olduğunu göstermek istemektedir. Rusya otuz yıldan fazla süren araştırmalarına dayanarak 
Lomonosov ve Mendeleyev sırtlarının Rusya Arktik topraklarının doğal bir uzantıs1 olarak kabul edilmesi gerektiğini beyan etmiştir. Yaptığı araştırmalar neticesinde buradaki sırtların kabuğunun okyanus tipinde değil, kıtasal tipte olduğunu belirlemiştir (Matveyeviç,2011). Rusya ortaya koymuş olduğu bilimsel verilere bağlı olarak kıta sahanlığının genişletilerek yeniden belirlenmesini talep etmektedir. Bunu da BMDHS'nin 76. Maddesine dayanarak yapar. BMDHS'nin 76. Maddesi'ne göre; "Sahildar bir devletin kıta sahanlığı, kara sularının ötesinde kıta kenarının dış eşiğine kadar veya bu eşik daha az bir mesafede ise, kara sularının ölçülmeye başlandığı esas hatlardan itibaren 200 deniz mili mesafeye olan kısımda, bu devletin kara ülkesinin doğal uzantısının bütünündeki denizaltı alanlarının deniz yatağı ve toprak altlarını içerir" (http://www.unicankara.org.tr/ doc_pdf/denizhukuku.pdf) (s.26).

Buna bağlı olarak kara ülkesinin doğal uzantısı kabul edilen deniz altındaki alanlar o ülkenin egemenlik alanına dâhil olmuş olur. Rusya Lomonosov sırtını Sibirya'nın kuzey kıyılarından dik olarak çıkan su altı sırtı olarak kabul ederken (Bu sırt Sibirya'nın kuzey kıyılarından 2300 km uzağa uzanmaktadır) diğer taraftan Danimarkalı ve Kanadalı bilim insanları Lomonosov sırtının Kuzey Kutbu altından geçtiğini, jeolojik olarak Kuzey Amerika ve Grönland plakalarına bağlı olduğunu ve Rusya'nın kıta sahanlığının devamı olamayacağını iddia etmektedirler (http://library.narfu.ru).

Arktikte jeolojik alanlar üzerindeki hukuki egemenlik iddiaları sadece bunlarla sınırlı değildir. Diğer bir husus ise münhasır ekonomik alanlar üzerindeki çekişmedir.

Bilindiği üzere, münhasır ekonomik bölgede kıyı devleti belirli konularda münhasır yetkilere sahiptir. Bunlar arasında diğer devletlerin belirli faaliyetlerini düzenleyip, men etme de yer alır. Yapay ada ve tesislerin kurulması, bilimsel araştırma yapılması bunlardan bazılarıdır. Fakat BMDHS'nin 246. Maddesi, insanlığın yararına olacak bilimsel araştırmaların keyfi reddedilmemesi gerektiğinden bahseder (Sur, 2010: 343). Münhasır alanlarla ilgili çekişmeli pozisyonlar yaratacak bu maddenin önemli görülen 3 şartı şöyledir:

- "Madde 246/1. Kıyı devletleri bu sözleşmenin ilgili hükümlerine uygun olarak yargı yetkilerini kullanırken kendi münhasır ekonomik alanlarında ve kıta sahanlıklarında yapılacak olan bilimsel araştırmaları düzenleme, yetkilendirme ve yönetme hakkına sahiptirler. 
Uluslararası Hukuk Çerçevesinden Arktik Güvenliği Politikalarının Analizi:

Rusya ve ABD Örneği

- 246/2. Münhasır Ekonomik Bölge ve Kıta Sahanlığı içindeki bilimsel araştırmalar kıyı devletinin izni ile yapılmalıdır.

- 246/3. Kıyı devletleri normal şartlar altında, diğer devletler ya da yetkili uluslararası örgütler tarafından kendi Münhasır Ekonomik Bölgeleri ya da Kıta Sahanlıklarında bu sözleşmeye uygun olarak yalnızca barışçıl amaçlarla, tüm insanlığın yararına deniz çevresine ait bilimsel bilgiyi arttırmak için yürütülecek olan bilimsel araştırma projelerine onay verir. $\mathrm{Bu}$ amaçla kıyı devletleri böyle bir iznin sebepsiz nedenlerle ertelenemeyeceği ya da reddedilemeyeceğine ilișkin olarak kurallar ve prosedürler oluşturması gerekmektedir" (http://www.un.org/depts/los/ convention_agreements/texts/unclos/unclos_e.pdf) (s.119).

Rusya, Arktik Okyanusu'ndaki münhasır ekonomik bölgesine ABD'nin araştırma yapmak için girişine 1998 yılından beri müsaade etmemektedir ( Moore, 2004: 20). Anlaşılan şudur ki, Rusya 12 Mart 1997 tarihinde BMDHS'ni onayladıktan sonra sözleşmenin yukarıda üzerinde durulan 246. Maddenin 1. ve 2. Bentlerine göre sahildar ülkelere sunduğu egemenlik haklarından yararlanarak, Arktik'teki yabancı devletlerin faaliyetlerine izin vermemektedir. Fakat 246. Maddenin 3. Bendi sebepsiz yere reddetmelerin önünde bir engel oluşturmaktadır. Rusya'nın bu duruma karşı makul bir neden göstermiyor oluşu ise onun elini zayıflatmaktadır. Fakat BMDHS'nin 77. Maddesi konuyla alakalı bir çelişki olușturmaktadır.

77. Madde'nin 2. Bendi kıta sahanlığına ilişkin tüm izin ve onayları sahildar ülkenin egemenlik alanı içinde kabul etmektedir (http://www.unicankara.org.tr/doc_pdf/denizhukuku.pdf) (s.27). Bu yüzden ABD'nin, Rusya'nın onayını almadıkça anlaşmada belirtilen faaliyetlerde bulunmasının uluslararası hukuk açısından uygun olmayacağı düşünülmektedir.

Fakat ABD her halükarda, BMDHS Madde 256'dan doğan haklarını bu bölge üzerinde işletmek isteyebilir. Madde 256 tam olarak şöyle der: Coğrafi konumlarına bakılmaksızın tüm devletler ve yetkili uluslararas örgütler, XI. Bölümün hükümlerine uygun olarak bölgede deniz bilimi araştırması yapma hakkına sahiptir (http://www.un.org/depts/los/ convention_agreements/texts/unclos/unclos_e.pdf). XI. Bölüm ulusal yargılama sınırları ötesinde kalan deniz yatağı, okyanus zemini ve bunun toprak altını belirten ve BMDHS'nde "Bölge" (Area) olarak geçen "Uluslararası Deniz Yatağı" ile ilgilidir. Madde 141'de Bölge'nin, denize kıyısı bulunsun ya da bulunmasın tüm devletlerin sadece barışçıl amaçlarla 
kullanımına açık olacağı belirtilmiştir. Kıyı devletlerinin meşru çıkarları ve hakları ayrıca 142. Maddede açıklanmıştır (http://www.un.org/depts/los/ convention_agreements/texts/unclos/unclos_e.pdf). ABD'nin "Bölge" üzerinde herhangi bir faaliyette bulunması için yine ilgili kıyı devleti ile istişare halinde olması gerekecektir. Rusya'nın rıza göstermediği herhangi bir hususta ABD'nin Rus Arktik alanında araştırma yapması olanaksız gözükmektedir.

Rusya Arktik politikalarında kıyı ve denizalanı güvenliğinin sağlanmasına hayati derecede önem vermektedir ve BMDHS'nden doğan hakları uyarınca ABD'nin Arktik politikası ile karşı karşıya gelmektedir. Arktik Bölgesi'nin sahip olduğu muazzam enerji kaynaklarının küresel güvenlik alanının bir parçası olduğu gerçeği iki ülkenin politik gündeminde yer almaktadır. Dünyada enerji kaynaklarına olan ihtiyacın giderek artıyor olması aslında ABD ve Rusya dışında birçok ülkenin Arktik'le daha fazla ilgilenmesine neden olmaktadır. Bilinmelidir ki, Arktik aynı zamanda bölgeye kıyısı olmayan ülkelerin de üzerinde çeşitli faaliyetler yürütebileceği bir "açık deniz" alanına sahiptir. Bu açık denizin varlığ bölgede herhangi bir kıyısı bulunmayan diğer devletleri de ilgilendiren bir husus olmuştur (http://www.scmp.com).

Geleneksel olarak 1958 Cenevre Açık Deniz Sözleşmesindeki tanımdan hareket edilirse, açık deniz hiçbir devletin karasularına dâhil olmayıp, herhangi bir devletin egemenliği altında bulunmayan deniz alanları olarak tanımlanabilir (Sur, 2010, 352). Uygulanan uluslararası hukuka göre ise "açık deniz", iç sular, karasuları, takımada devletlerinin takımada suları ve münhasır ekonomik bölge dışında kalan deniz alanını kapsamaktadır (Pazarc1, 2010, 289).

Öyle ki Deniz Hukuku Sözleşmesi'nin 7. Bölümü 1. Kısımında yer alan 87. Maddenin öngördüğü şekli ile Açık denizler ister bir sahili bulunsun isterse de denize hiç bir kıyısı bulunmasın, tüm devletlere açıktır. $\mathrm{Bu}$ hüküm ayrıca, açık denizlerde seyrüsefer yapma, uçuş yapma, deniz altına kablo ya da borular döşeme, yapay adalar ile tesisler inşa etme, balıkçılık yapma ve bilimsel araştırma yapma hususlarındaki özgürlükleri de kapsar (http://www.un.org/depts/los/convention_agreements/texts/unclos/ unclos_e.pdf) (s.57).

ABD BMDHS'ni onaylamadığı için kıta sahanlığını genişletme hakkından yararlanamamaktadır. Arktik kaynakları kendi yargı alanı dışında kalmaktadır. Bundan dolayı Çin gibi Arktik konseyinde gözlemci 
Uluslararası Hukuk Çerçevesinden Arktik Güvenliği Politikalarının Analizi:

Rusya ve ABD Örneği

statüsündeki ülkeler ABD'nin Arktik sahanlığında sondaj yapma hakkı elde etmiş olacaktır (http://mixednews.ru).

Bunun dişında Hindistan'ın da Arktik konusu ile ilgilenmeye başladığı ve bu bölgeyi öncelikli alan olarak görmesi şaşırtıcı değildir. Çünkü Arktik’teki buzulların erimesi sonucu yükselen deniz seviyesi Hindistan'da yaşayan 100 milyon kadar insanın geçimini tehdit etmektedir (http://www.lgz.ru). Hindistan'ın bu hususu ulusal güvenlik meselesi olarak kabul etmesinin önünde hiçbir engel bulunmamaktadır. Öyle ki, Arktik Konseyinde gözlemci statüsü elde etmeyi dahi başarmıştır. Anlaşılmaktadır ki, Arktik Okyanusu'na kıyısı dahi bulunmayan birçok ülke dolaylı ya da dolaysız Arktik politikaları ile alakadar olabilmektedir.

Bölgede başlayan bu değişimin tüm gezegen üzerinde etkili olarak çeşitli çevresel olayları tetikleyebileceği ve bunun da dünya düzeni için büyük risk yarattığı düşünülebilir. Arktik artık uluslararası bir sorun alanı olarak gündemlerimize girmiş bulunmaktadır. Bu sorunu bölgeye en fazla sınırı bulunan Rusya'nın daha fazla içselleştirmiş olması da şaşırtıcı bulunmamaktadır. Çünkü Rusya BMDHS uyarınca belirlenecek Arktik sınırları üzerinde (Özellikle Kıta sahanlığı sınırlarında) tüm tarafların mutabık kalmasını sağlamayı hedeflemektedir. Böylece Rusya belirlenen alanlarda tam anlamıyla bağımsız kararlar alma hakkına kavuşacaktır. Rusya'nın özellikle son dönem politikalarında bu durum üzerinde çalıştığ 1 açıkça gözlenmektedir.

\section{Rusya'nın Arktik Politikası}

Arktik Bölgesi Rusya için başta kendi kıyı güvenliğini sağlamak adına iç güvenliğiyle alakadar iken diğer yandan, bölgedeki kıyıdaş ülkelerle olan münasebetlerinde BMDHS'nin kendisine sunmuş olduğu haklarını korumak adına dış güvenlik alanıyla alakadardır. Bu yüzden hem iç hem de dış politikasında Arktik'e özel önem vererek her iki alandaki güvenlik ölçütlerini bir düşünmektedir.

"Rusya Federasyonu; Rusya Arktik Bölgesi olarak belirttiği topraklar içinde; Sakha (Yakut) Cumhuriyeti, Murmansk ve Arkhangelsk bölgeleri, Krasnoyarsk toprakları, Nenets ve Yamal-Nenets ve Chukotka Otonom bölgesi yer alır. Arktik toprakları yukarıda belirtilen alanları kimi yerlerde bütün olarak kimi yerlerde ise kısmen içine almaktadır. Rusya bu topraklara bitişik adalar, iç sular, kara suları, münhasır ekonomik bölgesi ve 
kıta sahanlığı üzerinde uluslararası hukuk kuralları uyarınca egemenlik hakkına ve yarg1 yetkisine sahiptir" (http://government.ru/info/18359/).

Rusya 1989 yılında Arktik ile ilgili olarak yasal sınırını yukarıda ifade edildiği şekliyle belirlemiştir. Bu bölgelerle alakalı olarak aktif bir politika oluşturmak için ise Rusya Federasyonu'nun eski gücünü yeniden kazanması ve iç politika sorunlarını bertaraf etmesi gerekmiştir. Bu yüzden Rusya'nın Arktik politikalarını uygulama süresi gecikmiştir. Bu bağlamda Rusya'nın Arktik politikalarını gerçekleştirmesi 2008-2020 yılları arasında olmak üzere 3 önemli zaman dilimine yayılmıştır. Bunlardan ilki 20082010, ikincisi 2011-2015 ve üçüncüsü ise 2016-2020 y1lları olarak belirtilmiştir (http://government.ru/info/18359/).

Bunun için ilk olarak denizlerde yasal bir düzenleme ihtiyacı doğmuştur. Rusya Federasyonu Arktik politikasının da içinde yer aldığ Denizcilik Doktrini (Морская доктрина-Naval Doctrine) 2001 yılında imzalanmıştır. Temel Denizcilik Doktrini olarak bilinen bu doktrin 2020 y1lına kadar geçerli olacak şekilde düzenlenmiştir. Bu doktrinin 59,60 ve 61 . Maddeleri Arktik Bölgesi ile ilgilidir (http://static.kremlin.ru') Bu doktrinin belirli kısımları revize edilmiş ve 2015 yılında bu kez 2030 yılına kadar geçerli olacak yeni Denizcilik Doktrini imzalanmıştır. Bu doktrinde iki en önemli temel çalışma alanı olarak Atlantik ve Arktik Okyanusları belirlenmiştir (http://kremlin.ru/events/president/news/50060).

Yine son dönemlerde Rusya Federasyonu Devlet Başkanı 20.07.2017 tarihli 327 Sayılı Kararnamesi'nin 24. Maddesi a) bendinde Arktik bölgesinden de tehdit algıladığına vurgu yapılmıştır (http://kremlin.ru/acts/bank/42117).

$\mathrm{Bu}$ gibi düzenlemeler dışında Arktik'le alakalı yayınlanmış Strateji 2008-Strateji 2013 belgeleri de bulunmaktadır (Heininnen, 2014: 16-20). Arktik bölgesi ile alakalı Rusya Federasyonu'nun ortaya koymuş olduğu ilk ciddi çalışma olarak bilinen strateji-2008, Medvedev başkanlığ 1 döneminde yapılmıştır (http://government.ru/info/18359/). Rusya Federasyonu'nun ilk olarak ulusal çıkarları esas aldığı devlet politikasının temelleri böylelikle atılmıştır. 2008 strateji belgesi olarak bilinen bu belgede Arktik kaynaklarının projelendirilmesi, Kuzey Deniz Rotasının ulusal entegre ulaşım hattı olarak belirlenmesi, gelecekteki stratejik kaynak üssü olarak bu bölgenin tayin edilmesinin sağlanması, bölgenin eşsiz ekolojik doğasının korunmas1 (http://government.ru/info/18359/) gibi bir dizi görev beyan edilmiştir. Arktik bölgesi için askeri, sosyo-ekonomik ve ekolojik güvenlik 
Uluslararası Hukuk Çerçevesinden Arktik Güvenliği Politikalarının Analizi:

Rusya ve ABD Örneği

meseleleri ön planda tutulurken bilgi ve teknolojileri, uluslararası iş birliği konularına da stratejik öncelik verilmiştir.

Diğer strateji belgesi ise 2013 yılında Putin döneminde hazırlanmıştır. 2013 belgesi ise daha çok Arktik bölgesinin gelişimi ve ulusal güvenliğinin sağlanmasına odaklanmıştır. Bunun için, Rus Arktiğinde sosyo-ekonomik gelişimi sağlamak, bilim ve teknolojiyi geliştirmek, çağdaş bilgi-telekomünikasyon altyapısı kurmak, ekolojik güvenliği sağlamak, Arktikte işbirliğini sağlamak, Rusya Federasyonu'nun Arktik sınırlarını korunmak savunmak ve askeri güvenliği sağlamak (http://government.ru/info/18360/) bu belgenin en önemli hedefleri arasindadir.

Örneğin, Askeri güvenlik çerçevesinden ele alındığında Rusya, silahlı kuvvetleri ile bölgeye elverişli operasyonel birlikleri konuşlandırma ve böylece toprakların güvenliğini sağlama niyetinde olduğunu ifade etmiştir. Ayrıca kıyıların korunmasını sağlamak amacıyla aktif olarak çalışacak fonksiyonel bir federal sahil güvenlik sistemi oluşturulmasının gerekli olduğuna değinmiştir. Bu yapılması planlanan eylemler Rusya'nın sadece toprak güvenliği için değil bölgedeki ekonomik çıkarlarını korumak için de birtakım görevler ifa edeceğini açıkça ortaya koymaktadır (http://government.ru/info/18359/). Bu görevler bazen egemenlik iddialarını bazen de genişleme iddialarını destekler niteliktedir.

Öyle ki, Rusya doğrudan kıta sahanlığına bağlı olduğunu savunduğu Lomonosov sırtına titanyumdan yapılan 1 metre yüksekliğindeki Rus bayrağını dikerek egemenlik iddiasında da bulunmuştur (Parfitt, 2007). Rusya Devlet Başkanı Putin, Başbakan Medvedev, Savunma Bakanı Şoygu'nun da katılmış olduğu Franz Josef takımadalarına olan ziyarette Rusya, bu takımada üzerindeki hâkimiyetini pekiştirme yolunda bir dizi önlem almıştır, bu ziyaretin amacı ise Arktik bölgesinde Rusya'nın rolünü göstermek şeklinde algılanmıştır (https://www.unian.net).

Diğer yandan Arktik bölgesinde buzulların erimesi ile birlikte Kuzey Deniz Yolu'nun (Северного Морского Пути-СМП, Northern Sea Route) Rusya'ya önemli derecede ekonomik kazanç getirmesi beklenmektedir. $\mathrm{Bu}$ yol geleneksel ticaret yolu olarak kabul gören güzergâhlardan çok daha kısa bir yol olması dolayısıyla önem arz etmektedir. Bu yolun işlevsel hâle gelmesi şüphesiz hem iç hem diş ticarette Rusya'nın elini güçlendirecektir. Rusya'nın dünyanın en güçlü Buz Kırıcı filosuna sahip olması da O'na bu konuda avantaj sunmaktadır ( Konişev ve Sergunin, 2011: 14). 
Bu buz kırıcı gemiler Rusya'nın Arktik'teki sahip olduğu tüm sahil şeridi boyunca gözlemlenmektedir. Savaş zamanında bu gemilerin kolaylıkla toparlanıp Rus savaş gemileri için bölgede kanallar açabileceğine dikkat çekilmiş ve ABD'nin bu gemilere çok fazla yatırım yapmadığı dile getirilmiştir. Buna karşı ABD'nin ise hem savaş hem de barış zamanı aktif olarak kullanılabilen deniz altılar ile etkisini ortaya koyabileceği değerlendirilmektedir (Axe, 2015).

Savaş anında Kırım'da konuşlanmış olan Karadeniz donanması bir NATO ülkesi olan Türkiye'nin boğazları kapatması halinde işlevsiz kalacaktır. Bu durum Rusya'nın Baltık'taki donanması için de geçerlidir. NATO, Danimarka ve Norveç arasındaki Skagerrak boğazının kapattı̆̆ zaman Rusya aynı senaryo ile karşı karşıya kalabilir. Bu durumda en iyi opsiyon Arktik okyanusudur - Atlantik'e engelsiz bir geçiş olanağ1 sunar (Bittner, 2016: 2).

Rusya aynı zamanda Arktik bölgesinde Sovyetler döneminden kalan askeri üsleri yeniden açmış ve bu bölgede füzeler için erken uyarı radar sistemi kurmuştur (Mortimer, 2017). Rusya'nın bölgede hem hücum hem de savunma unsurları ile birlikte varlığını arttırması oldukça dikkat çekmiştir.

Özellikle Batılı ülkeler, Moskova'nın Arktik’teki varlığını kendileri için bir tehdit unsuru olarak görmektedirler. Bu fikre dayanarak da hem NATO hem de NATO'nun dışında çok uluslu askeri işbirliğini güçlendirmeyi planlamaktadırlar (Konişev ve Sergunin, 2011: 18) $\mathrm{Bu}$ duruma karşı Rusya'nın Arktik bölgesi için düşündüğü güvenlik alanının sadece Arktik ile sınırlı kalmayacağı düşünülebilir. Ayrıca günümüz koşulları dikkate alındığında sadece askeri güvenliğin yeterli olmayacağ 1 açıktır. Bu yüzden Rusya iç siyasi dinamiklerini de değerlendirerek bu bölge üzerinde geniş kapsamlı güvenlik çalışmaları yapmaktadır.

Polovinkin ve Fomiçev'in belirttiği gibi; iç politikada ulusal güvenliğe yönelik olan tehditler, Rusya'nın kuzey bölgelerindeki sosyoekonomik gelişmelerdeki mevcut problemlerden ileri gelmektedir ve bu belli başlı alanlarda Rusya Federasyonu'nun kuzey bölgelerindeki nüfus grupları içinde ayrılıkçı isteklerin provoke edebilir hâl almasını olanaklı k1lmaktadır (2013:63).

Yabanc1 ülkeler, başta Rusya Federasyonu'ndan toprak talebinde bulunanlar dâhil, bu istekleri yapay olarak hararetli bir hâle getirebilirler. Rus yönetimine göre ise, Arktik'te devlet politikasının uygulanıyor olması Rusya'nın lider Arktik gücü olma rolünün korunmasını mümkün kılacaktır (Polovinkin ve Fomiçev, 2013:63). 
Uluslararası Hukuk Çerçevesinden Arktik Güvenliği Politikalarının Analizi:

Rusya ve ABD Örneği

Rusya'nın Arktik politikasının aslında tüm ülke kalkınması ile alakadar olduğu belirtilmiştir. Çünkü Kuzey bölgesinde yapılacak olan akıllıca araştırmalar Rusya'yı kısa zamanda tüm dünyanın lideri pozisyonuna getirecektir (Polovinkin ve Fomiçev, 2013:62).

$\mathrm{Bu}$ yüzden, Rusya kuzey bölgelerinde yaşayan yerli nüfus ile ilgili olarak da geçmişten günümüze dek çeşitli politikalar üretme çabası içine girmiştir. Öyle ki, bu çerçevede bazı yasal düzenlemelere dahi gidildiği gözlenmiştir. Yapılan düzenlemelere göre, Rusya Federasyonu 1993 Anayasası, uluslararası anlaşmaların genellikle kabul edilen prensip ve normlarına uygun olarak yerel halkların temel haklarının, geleneksel yaşam şekillerinin, doğal yaşam alanlarının korunmasını garanti etmektedir. $\mathrm{Bu}$ konu çerçevesinde 1999, 2000 ve 2001 yıllarında Federal hukukta da bazı kanunlar çıkarılmıştır (Tişkov vd., 2016: 24). Bu kanunların uluslararası hukuk nezdinde de karşılığı bulunmaktadır.

Örneğin; 2007 yılında BM Genel Kurulu, Yerel Halkların Hakları Deklarasyonu'nu kabul etmiştir. Bu Deklarasyon yerli halklar üzerinde alınabilecek tüm tedbir ve uygulamalara yönelik olarak bir düzenleme sunmakla birlikte bu halkların haklarının ulusal hukukta da yer alması için gerekli tedbirlerin alınmasını salık vermektedir. Bu yüzden ilgili kısımlarda direkt devletlerin yapması gereken faaliyetleri de belirtmektedir (http://www.un.org/esa/socdev/unpfii/documents/DRIPS_en.pdf). Yerel yaşama dair değer ve kazanımların korunmasına yönelik yapılan uluslararası düzenlemelerin, ulusal boyutta benzer düzenlemelerle yasal hâle getirilmesi yine uluslararası toplumun çok yakından takip ettiği bir konu olarak karşımıza çıkmaktadır. Yerli halkların yaşam hakkı bir güvenlik sorunu olarak kabul edilmekte ve devletlerin uluslararası kanunlara uygun olarak bu halkların güvenliğini sağlamaları talep edilmektedir.

Yine de uluslararası toplum yerel halkların durumundan endişe duymakla birlikte, onların problemlerini çözecek, yerli halkların modern şartlarda gelişimlerini sağlayacak, sadece kültür ve dillerinin korunmasını değil aynı zamanda onların sahip oldukları becerilerinin de tüm toplum seviyesinde korunmasını garanti edecek yolları araştırmaktadır (Tişkov vd., 2016: 59). Rusya'da bu kapsamda birçok endüstri şirketinin yönetimleri, özellikle yerel halkların geleneksel yerleşim yerleri ve ekonomik aktiviteleri ile alakalı bir dizi sorumluluk altına girmişlerdir (Tişkov vd., 2016: 23). Tüm bu düzenlemeler yasal çerçevede yapılmaktadır. Rusya Kuzey bölgelerinde yaşayan yerel halklar konusunda uluslararası hukuk kurallarına riayet ederek oldukça hassas bir politika yürütmektedir. 
Diğer taraftan bölge tüm dünyadaki ekolojik dengeye etki edecek kapasitesi dolayısıyla ülke politikalarında yerini almaktadır. Rusya için Ekolojik güvenlik çok önem arz etmektedir. Uygulanacak politikalarda ilk önce bu zengin doğanın nasıl korunması gerektiği sorusuna bir cevap aranmaktadır. Çünkü erime ile birlikte doğal zenginliklere erişimin kolaylaşması bölgenin daha manipüle edilebilir bir pozisyona gelmesine neden olabilmektedir. Bu yüzden Rusya bölge ile ilgili ekonomik politikalarını da hukuki zeminde yürütmek zorunluluğundadır. Bu hukuki altyap1 doğal erimenin Kuzey Buz denizinde oluşturduğu yeni geçiş güzergâhlarının belirlenmesi ve kullanımını da yakından etkiler. Yeni ticari bölgelerin gelişmesi ile birlikte de yeni hukuk rejimlerinin ortaya çıkması kaçınılmaz olur. Ruslara göre de Kuzey Deniz Yolu ve onun altyapısının canlanması Arktik bölgesinin ekonomik öneminin yani Arktik denizlerinde transit taşımacılığın cazibesinin artmasına bağlıdır. Bu cazibe de Kuzey Buz Denizi yatağında petrol ve gaz keşiflerinin yapılması ile başlar (http://www.arctic-info.ru).

Veriler Arktik bölgesinde bulunan hidrokarbon rezervlerinin birçoğunun Rus Arktik Alanı'nda yer aldığını göstermektedir. Rus jeologların bölgedeki araştırmaları sonucunda 200 yeni petrol ve doğal gaz sahası keşfedilmiştir. Ayrıca Arktik alanında yer alan Barents ve Kara deniz sahanlıkları içinde 22 büyük ölçekli petrol sahası bulunmuştur (Heininen, Sergunin, Yarovoy, 2014, s.10). Bu sahaların dünya enerji piyasalarında yaratacağı etki söz konusu olduğunda bölgenin hukuki işleyiş düzenine daha fazla ihtiyacı olacağı kesindir. Rusya Arktik bölgesinde en fazla toprağ 1 bulunan ülke olması dolayısıyla olumlu ya da olumsuz tüm işleyişten en çok etkilenecek olan ülke konumundadır.

Rusya Petrol ve Gaz Diyaloğu forum başkanı Nina Pusenkov, Rusya'nın 6,2 milyon $\mathrm{km}^{2}$ ile dünyadaki en büyük kıyı sahasına sahip olduğunu fakat bunun çok az bir kesiminde keşif taramaları yapıldığını, zaten Arktik petrolü ve gazının çok fazla maliyetli olacağını da belirtmiştir (Vinogradov, 2013). Bu bağlamda Rusya'nın daha fazla teknolojik yatırımla bu giderlerin minimalize edilmesi üzerinde çalışacağı tahmin edilmektedir.

2010 yılında BP'nin Meksika Körfezinde yaşadığı kazadan sonra çevreciler bu durum karşısında oldukça endişelenmişler ve herhangi bir petrol sızıntısının Arktik sularında da doğal yaşamı tehdit edebileceği üzerinde durmuşlardır. Uzmanların görüşüne göre bölgede petrol keşifi veya çıkarılması sırasında oldukça riskli durumlar meydana gelmektedir. Petrol şirketleri ilk olarak yerleşik halkın ve doğal ekolojik sistemin menfaatlerini 
Uluslararası Hukuk Çerçevesinden Arktik Güvenliği Politikalarının Analizi:

Rusya ve ABD Örneği

gözetecek biçimde düzenlemeler yapmalıdır. Ayrıca bölgede gerçekleştirecekleri eylemlerin güvenli olduğuna dair bir garanti vermeleri gerekmektedir (Kai ve Filetova, 2013).

Zaten BMDHS'de 12 Bölüm'e ilişkin olarak Deniz çevresinin korunması adına bir dizi hüküm yer almaktadır. Rusya da BMDHS'ni imzalayıp onaylayan diğer ülkeler gibi bu hususları göz önünde bulundurularak yine 13. Bölüm Kısım 3 ve 4 te yer alan Denizlerde Bilimsel araştırma yapma kuralları çerçevesinde hareket etme imkânına sahiptir. Fakat bu hareketler tüm uluslararası hukuk kuralları gözetilerek yapılmalıdır. Zira Rusya bununla ilgili bir problem yaşamıştır.

Rusya'nın Arktik bölgesinde karşılaşmış olduğu bu sorun Greenpeace'e ait olan bir geminin Rusya'nın Arktik bölgesindeki Münhasır Ekonomik bölgesi içine izinsiz girmesi sonucunda meydana gelmiştir. Greenpeace'in Hollanda bayrağı altında aktivitesini gerçekleştirmesi dolayısıyla Hollanda UDHM'de (Uluslararası deniz Hukuku MahkemesiITLOS-International Tribunal for the Law of the Sea) Rusya Federasyonu aleyhinde dava açmıştır. Dava sonucunda geçici tedbir kararları alınmış ve bu kararlara göre Rusya'nın gemiyi ve mürettebatını serbest bırakması gerektiği belirtilmiştir (https://www.itlos.org). Fakat Rusya mahkemeye katılmamıştır. Dava tahkime gitmiştir. Lahey'deki Tahkim Mahkemesi Rusya'nın BMDHS'nden doğan haklarını kötüye kullandığına hükmetmiş ve Rusya'yı Hollanda'ya tazminat ödemeye mahkûm etmiştir (http://www.bbc.com).

Sonuç olarak, Rusya Arktik'teki mevcudiyetini BMDHS'ne dayandırarak belirli bir takım eylemler gerçekleştirecek ise bu pratiklerini başta uluslararası hukukun iyi niyet prensibini gözeterek, tamamıyla uluslararası hukuka uyumlu bir çerçevede yapması gerekmektedir. Aksi takdirde BMDHS hükümleri devletler ya da diğer aktörlerin denizlerdeki davranışları ve birbirleri arasında yaşanan sorunların çözümü aşamasında işlevsiz kalmaktadır. Bu durum en fazla anlaşmayı onaylamayan ABD'nin Arktik'teki münhasır alanlar konusunda yaşadığı sıkıntılarda karşısına çıkmaktadır.

\section{ABD’nin Arktik Politikası}

Bilindiği gibi 1945 tarihli Truman Bildirisi, ABD kıta sahanlığ içinde bulunan kaynaklar üzerinde sadece ABD'nin yarg1 yetkisi bulunduğunu iddia etmektedir. $\mathrm{Bu}$ bildiri; karasuları, balıkçılık ve 
ekonomik bölgeler gibi konularda, tüm dünyada sahildar devletler tarafından ortaya atılan hak iddialarının patlak vermesinde değim yerindeyse ilk yaylım ateşi olarak görülmüştür (Browne, 2006: 4). ABD uzunca bir süre kendi kıyı şeridi ile ilgili düzenlemeleri bu bildiriyi esas alarak yürütmüştür. Bununla birlikte özellikle denize kıyısı bulunan devletler deniz alanlarında geçerli olacak ortak bir yasal düzenlemeye ihtiyaç duymuşlardır. $\mathrm{Bu}$ bildiri, söz konusu ihtiyacın karşılanması noktasında diğer devletlere de rehberlik ederek, ilk olarak 1958 Cenevre Kıta Sahanlığı Sözleşmesi'nin oluşumunda önemli rol oynamıştır. İlerleyen tarihlerde uluslararası anlamda bir dizi hukuk konferansı icra edilmiş ve nihayetinde 1982 tarihli BMDHS ortaya çıkmıştır.

Başlangıçta ABD'nin yanında BMDHS'ne katılmak istemeyen birçok ülke bulunuyordu. Özellikle bu ülkeler, madencilik teknolojisini az gelişmiş üye ülkelere transfer etme, lisans ücretlerini dağıtma vb. gereklilikleri ortaya koyan derin deniz yatağ 1 madencilik rejimine karşı duran ülkelerdi (Mirasola, 2015). ABD ve diğer gelişmiş ülkeler sahip oldukları teknolojik avantajları paylaşmak yerine kendi çıkar alanının koruma ve arttırma yolunu seçmişlerdi.

Anlaşma yeniden müzakere edildi ve 1998 yılında sonuca kavuşturuldu. Sanayileşmiş ülkeler dâhil olmak üzere 166 ülke BMDHS'ni imzaladı. ABD'de o tarihten beri sirasiyla Clinton, Bush ve Obama yönetimlerinin hepsi, bu anlaşmayı Senato'nun onaylamasını 1srarla tavsiye ettiler (Mirasola, 2015). Fakat günümüze dek BMDHS Amerikan Senatosu tarafindan onaylanmadi.

Arktik ile ilgili yasal prosedür de 1982 yılında yapılan BMDHS ile sağlanmaya başlandı ve bu metinde bahsedilen prensiplere ABD dahil tüm sınırdaş Arktik ülkeleri riayet etmektedirler. Fakat Arktik'te sınırı bulunup da bu anlaşmayı onaylamayan tek ülkenin de ABD olduğu dikkat çekicidir (Ragauskas, 2011).

Sözleşmeye taraf olmaması ile ABD'nin Arktik bölgesi üzerinde birtakım haklardan mahrum kaldığı düşünülmeye başlanmış ve çeşitli açılardan bir analiz meselesi olarak zaman zaman Amerikan gündemine taşınmıştır. Buna rağmen bu anlaşmanın yürürlüğe girmemesi hususunda birçok uzman ciddi tezler ortaya atmıştır. Zaten 1945'ten beri Amerikan başkanları ABD'nin deniz hakları ve sınırları ile ilgili bildiriler yayınlamakta, Kongre ise buna ilişkin yasalar çıkarmaktadır. Bunların hiçbiri, herhangi bir ulus, ulus topluluğu ya da bir bütün olarak uluslararası toplum tarafından reddedilmemiştir (Groves, 2012) Bir süper güç olmanın 
Uluslararası Hukuk Çerçevesinden Arktik Güvenliği Politikalarının Analizi:

Rusya ve ABD Örneği

verdiği ayrıcalıklı durumu yıllar boyu sürdüren ABD'nin kendi çıkarları açısından BMDHS'ni onaylamayarak sürdürmek istediği anlaşılmaktadır.

Rabkin'in dile getirdiği gibi ABD'nin BMDHS'ni onaylaması hâlinde kendini geçmişte olduğundan daha geniş kapsamda uluslararası denetime teslim etmeyi de kabul edecektir (2006: 9). Bu pek olası bir durum gibi gözükmemektedir. Çünkü mevcut uluslararası sistemi bile kendi kontrolünde görmeyi şiddetle arzu eden bir süper gücün, sahip olduğu haklardan vazgeçmesi gibi bir durum realiteden oldukça uzak bir ihtimaldir.

$\mathrm{Bu}$ anlaşmayı kongrede geçirecek olan senatörler arasında da BMDHS'ne taraf olma konusunda ciddi bir muhalefetten bahsetmek te olasıdır. Şöyle ki, en radikal muhaliflerin fikri, konvansiyonun imzalanması sonucunda ABD'nin savunma kapasitesinin azalacağı yönündedir. Ayrıca bu durum olumsuz birtakım sonuçları da beraberinde getirecektir. Bunlar kısaca şöyle belirtilmiştir: başvuracaktır.

Anti Amerikan olan bir dizi çevreci örgüt mahkemelere

- $\quad$ ABD'de 200 deniz mili dişında kalan yerlerde bulunan doğal kaynakları çıkarmak isteyen firmalar lisans almak zorunda olacak ve vergi masraflarını karşılamak durumunda kalacaktır.

- Konvansiyon doğal kaynakların geliştirilmesi konusunda potansiyel rakipler ile bir kısım teknolojinin paylaşımını, aynı zamanda; balıkçılık yapma koşullarının da gözden geçirilmesini gerektirmektedir.

- Kita sahanlığı sınırlarının deniz yatağının jeolojik yapısı uyarınca açıklığa kavuşturulacak olması, ABD sahil güvenliğinin Kanada'nın kuzeyindeki faaliyetlerinde bir kısıtlama yaratacağı anlamına gelmektedir.

- Anlaşmazlıkların olması durumunda ABD, Uluslararası Deniz Hukuk Mahkemesi'nin yargı yetkisi alanı içine girecektir (http://odynokiy.livejournal.com).

Aslına bakılacak olunursa ABD'nin Arktik bölgesindeki ilgi alanları daha çok çevresel meseleler ve gemilerin geçiş yollarının serbestliği üzerine olmuştur. ABD Arktik bölgesi üzerinde enerji tartışmaları yapmamıştır. Hâlihazırda Alaska'nın kıyı şeridi boyunca büyük petrol alanlarına sahip olmasına karşın ABD'nin 48 eyaletinde daha kolay ve düşük maliyetli olarak çıkarılabilen kaya gazı ve petrol alanlarını tercih ettiği gözlenmiştir. 
Kısacası ABD Alaska'daki kaynakları bile kullanma ihtiyacı hissetmemiştir (Virtanen, 2013: 34). Kaya gazı rezervlerinden dolayı Amerika'nın enerji konusunda daha farklı politikalar izlediği ve Arktik'teki enerji kaynakları konusuna daha duyarsız davrandığı gözlenmiştir.

Fakat son dönemlerde ABD'nin BMDHS'ni artık onaylaması gerektiğgi yönünde de birtakım görüşler ortaya atılmıştır. Özellikle Arktik'teki erime dolayısıyla bölgedeki denizcilik faaliyetlerinde yaşanan artış, Amerika'nın da bu konuda yeni önlemler almasına sebep olmuştur. Aslına bakılacak olunursa BMDHS denizlerde gezinme özgürlüğünün ötesinde Amerika'nın çıkarlarını savunmasına da imkân sağlamaktadır. Bu Konvansiyon Arktik'teki ticari nakliye rotalarında, deniz altı madenciliğinde, telekomünikasyon operasyonları ile diğer deniz ticareti alanlarında yatırım yapmak isteyen Amerikan işletmelerini desteklemektedir (Johnson, 2016). Çünkü BMDHS tüm faaliyetler için bir yasal zemin oluşturur ve Uluslararası Deniz Hukuku Mahkemesi (UDHM) bu faaliyetlerde oluşabilecek herhangi bir anlaşmazlıkta temel yarg1 organı olarak işlev görür. Bu yüzden şirketler yapacakları yatırımların yasal bir izlek çerçevesinde olmasını ve bu izleğin yatırımlarına garanti sağlamasını tercih ederler. Arktik'le ilgili olan yatırımların da gerek uluslararası bir alan olması, gerekse faaliyet alanlarının ciddi yatırımlar gerektirmesi sebebi ile yasal bir zeminde yapılması gerekmektedir. Örneğin; Lockheed Martin firma başkanının Senatoya göndermiş olduğu mektubunda güçlü bir şekilde ifade ettiği gibi firmasının deniz altındaki zenginlikler için ticari yarışa girmek istediğini fakat açık yasal haklarının belirtilemediği durumda yatırım risklerini üstlenemeyeceğini bildirmiştir (Patrick, 2012).

Amerika'nın y1llar boyunca BMDHS'nin onaylanıp onaylanmaması konusunda yaşamış olduğu bu çelişkili durumlar hükümetlerin ve başkanların politikalarına da yansımıştır. Şöyle ki, Arktik bölgesinde keşif yapılmasının dahi ekolojik felaket riski taşıdığını düşünen ve bu yönde hareket eden eski başkan Obama'ya karşı Trump, görev süresinin ilk yılında, Arktik sularında petrol sondaj çalışmalarının yapılabilmesi için bir yürütme emri imzalamıştır (Lefebvre, 2017). Bu durum ABD'nin Arktik politikalarında köklü bir değişime gittiğinin ilanı olarak anlaşılmaya başlanmıştır.

Hatta daha öncesinde ABD'de bazı kanun yapıcılar, analistler ve hükümet görevlileri Arktik bölgesinin çevresel, ekonomik ve jeopolitik gerçekleri karşısında hazırlanmakta diğer ülkelere göre geride kaldıklarını 
Uluslararası Hukuk Çerçevesinden Arktik Güvenliği Politikalarının Analizi:

Rusya ve ABD Örneği

açıkça itiraf etmişlerdir (Davis, 2015). Diğer ülkelerin Arktik politikalarına erişmek ancak 2000'li yılların sonlarında mümkün olmuştur.

Bilindiği üzere ABD Arktik politikasını ancak 9 Ocak 2009 tarihinde çıkarmış olduğu NSPD 66/HSPD 25, (National Security Presidential Directive 66/Homeland Security Presidential Directive 25) yönergesi ile belirlemiştir (O’Rourke, 2015: 7). 2010 ve 2013 yıllarında Ulusal Güvenlik strateji belgesinde de Arktik politikası yer almıştır. 2014'te yayınlanan Arktik Bölgesinde Ulusal Güvenliğin Uygulanması Planı ve 2015'te yayınlanan Arktik Girişimlerinde Koordinasyonu Arttırma ile İlgili Yürütme Emri ise bölgede yasal düzlemde yapılan çalışmalara dayanak oluşturmaktadır (O’Rourke, 2015: 8-12).

Aslında Soğuk Savaşın bitimiyle birlikte bazı Arktik ülkeleri bölgedeki bu durumun uluslararası işbirliğini arttıracak bir firsat alanı yarattığını düşünmüşler buna rağmen, ABD bu konuda oldukça isteksiz davranarak mevcut meselelerle ikili ilişkiler çerçevesinde uğraşmayı ya da bu sorunları tamamen görmezden gelmeyi tercih etmiştir (Huebert, 2009: 22). Bu davranışın altında yatan en büyük neden belki de diğer Arktik ülkelerinin sorunların çözümü için Uluslararası Hukuk uygulamalarına başvuracak olmalarıdır. Özellikle BMDHS'nin kılavuzluk edeceği bu tür ilişkilerde ABD'nin yukarıda adı geçen ulusal düzenlemeleri yapmış olması şaşırtıcı gözükmemektedir.

Tüm bu düzenlemelerden ABD yönetimlerinin Arktik politikalarının daha çok çevresel, ekonomik ve askeri güvenlik eksenli olduğu anlaşılmaktadır. Arktik bölgesinde özelde Alaska ile ilişiği bulunan ABD bu bölgenin kara ve deniz sahasında sayısız araştırmalar yapmışlardır. Mevcut veriler ABD Arktik bölgesindeki hidrokarbon rezervlerinin büyük bir çoğunluğunun Alaska'nın kuzey kısımlarında bulunduğunu göstermektedir. 1940'lardan günümüze dek ABD burada 78 ana petrol sahasını işletmeye açmıştır. Bunun 22'si Beaufort deniz sahasındadır. En büyük offshore alanları ise Endicott ( 80 milyon ton petrol) ve McIntyre'dır (83 milyon ton petrol ve 17 milyar $\mathrm{m}^{3}$ gaz) (Puşkaryev, 2012: 29).

Ayrıca, ABD Okyanus Enerji Yönetimi Bürosu (BOEM) vasıtası ile offshore petrol ve gaz programı oluşturmuştur. Yerel enerji üretimini arttırmak amaçlı 3 bölgeyi ise [Chukchi Sea (2016), Cook Inlet (2016), and Beaufort Sea (2017)] 2012-2017 yılları arasında kiralama yoluna gittiği gözlenmektedir (O'Rourke, 2015: 30).

Tillerson Exxon'un Ceo'su olduğunda, Arktik rezervlerini bulmak ve çıkarmak için Rusya'nın devlete ait olan petrol şirketi Rosneft ile 500 
milyar \$ değerinde bir anlaşma imzalamıştır. Bu anlaşma Rusya'nın Kırım'ı ilhak etmesinden sonra uygulanan ekonomik yaptırımlar altında durdurulmuştur. Buna karşı Exxon Karadeniz'de bir muafiyet yapılması konusunda Hazine bakanlığına başvuruda bulunmuş fakat bu talebi reddedilmiştir (Watson, 2017). ABD'nin bu husuta Rusya karşısında oldukça kararlı bir tutum sergilemesi her firsatta saldırgan olarak değerlendirdiği Rusya'nın askeri operasyonlarına karşı bir cevap niteliği taşımaktadır. Yani ABD ekonomik kazançlarını askıya alıp askeri güvenliğin daha ön planda tutulması gerektiği yönünde davranış sergilemiştir.

Son dönemlerde ABD kendisini ileride Arktik Okyanusu'nda meydana gelecek tartışmanın merkezine almak istediğini açıcça belirtmektedir. Bunun fiili göstergelerinden biri de ABD'nin iki Nükleer denizaltısını devriye görevini icra etmesi için Alaska'da yer alan Prudhoe Bay bölgesinin 150 mil kuzeyine göndermesi olmuştur (http://www.theguardian.com ). BMDHS'ni onaylamamış olmasına rağmen bu alanda bir hak iddiasında bulunuyor olması ABD'nin yerel hukuk kaynaklarını Uluslararası Hukuk kaynağı olarak görmeye devam ettiğini göstermektedir. Bu durum bölgede güvenlik endişelerinin oluşmasına mahal vermektedir.

Ayrıca, ABD özellikle Amerikan Arktik bölgesinde diğer güvenlik önlemlerini alma konusunda da 1srarcı davranmaktadır. 2020 yılında Eielson hava kuvvetleri üssünde 2 yeni F-35 savaş uçağı fillosunun konuşlanacak olması Alaska'nın jeostratejik önemini daha da arttıracaktır. Böylelikle ABD Hava Kuvvetleri'nin neredeyse tüm kuzey yarımkürede hava üstünlüğüne sahip olacağı tahmin edilmektedir. ABD'nin Alaska'daki askeri varlığı, hava ve deniz gücünün etkin bileşimi şeklinde düşünüldüğünde; O'nun bu bölgede yıllar boyu üstünlük elde etmesine dayanak oluşturacaktır (Anderson, 2016). ABD'nin Arktik'te güçlü bir askeri yapılanma içine girme çabaları Rusya'nın bu bölgede artan varlığına karşı duyduğu şüpheden ileri gelmektedir. Bu durum ABD'nin teyakkuz hâlinde olmasını gerekli kılmaktadır. Değim yerindeyse ABD, Arktik'teki askeri güvenlik politikasını Rusya'dan duyduğu tehdit algılaması üzerine inşa etmektedir (https://www.defense.gov/Portals/1/Documents/pubs/2016-Arctic-StrategyUNCLAS-cleared-for-release.pdf, s,10).

Diğer bir husus ise yerli halklar ve onların haklarının korunması hususudur. Alaska'da yaşayan yerli halklar konusunda Amerikan Kongresi'nin değişken politikalara sahip olduğu dikkat çekmektedir. Bazen 
Uluslararası Hukuk Çerçevesinden Arktik Güvenliği Politikalarının Analizi:

Rusya ve ABD Örneği

bu halkı yerli Amerikalılar (K1zılderililer/Yerliler) kategorisi içinde, kendine münhasır bir azınlık grup olarak kabul eder ve istikrarsız yapı sergilediğine hükmeder. Bazen de sadece Alaska'nın yerli halkının meseleleriyle ilişkili ayrı yasal düzenlemeler ortaya koyduğu gözlemlenir (Alaska Native Claims Settlement Act of 1971, Alaska National Interest Land Conservation Act of 1980) (Young, 1992: 88). Amerika Arktik ile son dönemlerde hatta yeni ilgilenmeye başladı denilebilir. Bu bağlamda Alaska ve Arktik çevresinde yaşayan halkların durumları ile ciddi anlamda ilgili olamamıştır.

Conley'in belirttiği gibi; "Arktik dairesinde yaşayan halklar kendilerini destekleyecek geçim kaynağına ihtiyaç duymaktadırlar ve özellikle Alaskalılar küresel enerji düzenindeki değișimin etkilerini hissetmektedirler. Onlarca yıl Arktik halkları yönetim ve gelişim arasında denge bulmayı başardılar, bugün eğitim alanı ile ekonomik alandaki imkânlarını geliştirip çeşitlendirme konusunda yardıma ihtiyaçları bulunmaktadır." (para. 11).

Kısacası ABD ilk olarak ekonomik ve askeri güvenlik alanı olarak gördüğü Arktik Bölgesinin sosyal-insani boyutu ile pek fazla ilgilenmemektedir. Fakat bu politik durum uluslararası arenada diğer devletlerin özellikle diğer Arktik ülkelerinin dikkatini çekmektedir. ABD'nin yerli halklar konusuna olan olumsuz tutumu tüm dünya tarafindan bilinmekteyken Alaska ve çevresinde yaşayan halklarla ilgili alacağı karalar uygulayacağı politikalar önem arz etmektedir.

Sonuç olarak Alaska'da yaşayan yerli halklar konusunda ABD'nin ciddi adımlar atması beklenmektedir.

\section{Sonuç}

Arktik Bölgesi'nde meydana gelen iklimsel değişimden tüm insanlığın etkilenecek olması bilim ve teknik sayesinde ispatlanmışken, ülkeler çıkar alanlarını genişletmek için savaş vermek yerine çevresel ve insani hususlarda daha itinalı politikalar üretmelidirler. Devletler bu açıdan başta canlı hayatın korunması ve sürdürülmesi adına güvenliği tesis edecek unsurlara yönelmelidirler. Buna Arktik dairesi içerisinde yaşayan yerel halkların karşılaştıkları yaşamsal tehlikeleri ortadan kaldırarak başlayabilirler. Rusya'nın iç hukukunda fazlasıyla üzerinde durduğu bu husus, ABD'nin ne federal ne de bölgesel hukuk kuralları içerisinde bir değer görmüştür. Özellikle 2007 y1lına kadar olan dönemde ABD’nin yerel 
halklar ile ilgili olarak uygulamaya koyduğu dikkate değer bir çalışma bulunmamaktadır. Bu yüzden ABD'nin en az Rusya kadar yerli halklar konusunda çalışmalar yapması ve bu insanların uluslararası hukuk kuralları çerçevesinde korunmasına dikkat etmesi gerekmektedir.

Yine Rusya'nın Arktik Bölgesi'ndeki ekonomik çıkarlarını korumak için diğer devletlere nazaran daha fazla askeri yapılanma içerisinde oluşu ve bunu her geçen gün giderek arttırması, tehdit algılamaları üzerinde ciddi etkiler yaratmaktadır. Rusya'nın bu askeri güvenlik politikaları karşısında ABD'nin de Arktik güvenliğini arttırıcı bir takım önlemler aldığı bunun en önemli ispatıdır. Bölgede artan silahlanma Arktik'e komşu diğer ülkelerin de gündemini meşgul etmekte ve ciddi rahatsızlık uyandırmaktadır. Rusya ve ABD'nin Arktik Bölgesi'nde farklı güvenlik kaygıları taşıyor olmaları ve karşılıklı olarak birbirlerinde güvensizliğe neden olacak girişimlerde bulunmaları bugün, Uluslararası Hukukun yol göstericiliğine her zamandan daha fazla ihtiyaç duyulduğunun bir kanıtıdır.

$\mathrm{Bu}$ yüzden her firsatta Uluslararası Hukuk temel alınarak sorunların çözüm bulması yolunda adımlar atılmalıdır. Uyuşmazlığa taraf olan ve kendilerini birer hukuk devleti olarak tanımlayan bu ülkelerin Arktik Okyanusunda özellikle BMDHS şartına uygun olmadan hareket etme alanları pek de mümkün gözükmemektedir. Çünkü uyuşmazlığın her iki tarafı BMDHS'nin kıta sahanlıkları, münhasır ekonomik bölgeler, açık denizler, uluslararası deniz yatağı gibi konularda yapmış olduğu ilgili düzenlemelere tabi olmaksızın hak talep etme imkânına sahip olamayacaklarının farkındadırlar. Egemenlik alanlarında yaşanan belirsizlik bu ortak alan üzerinde güvenlik risklerinin oluşmasına neden olacaktır. Böylece Arktik Bölgesi istikrarsız bir hâle dönüşecektir. Bu yüzden ilk olarak Arktik'teki egemenlik iddialarının hakkaniyet çerçevesinde ele alınarak BMDHS kapsamında bir çözüme kavuşturulması gerekmektedir. Bölgede yapılacak herhangi bir sondaj çalışmasının bile doğal yaşamı tehdit edecek ciddi güvenlik riskleri taşıdığı bilinmektedir. Bunun için ABD’nin de BMDHS'ni onaylayarak uluslararası hukukta yasal egemenlik alanını belirlemeli ve bu alan üzerinde olumlu ya da olumsuz herhangi bir vakanın sorumluluğunu almalıdır.

Ayrıca Rusya diğer devletlerin ve uluslararası aktörlerin haklarını görmezden gelerek sadece kendi çıkar alanını genişletmek için BMDHS'ni bir araç olarak kullanmamalıdır. Bu çalışmada bahsi geçen UDHM kararı bu bağlamda önemlidir. Arktik'te kıyısı bulunan devletler bu karar gereği 
Uluslararası Hukuk Çerçevesinden Arktik Güvenliği Politikalarının Analizi:

Rusya ve ABD Örneği

BMDHS'nin yanında diğer uluslararası hukuk kurallarına da uyumlu biçimde hareket etmelidirler.

Ayrıca Arktik Bölgesi tüm dünyaya sunmuş olduğu doğal zenginliklerin yanında, sonuçları öngörülemez tehditler yayıyor olması dolayısıyla da tüm insanlığın güvenlik meselesi olarak ele alınmayı hak etmektedir. Bu yüzden sadece bu bölgeye sınırı bulunan ülkelerin hâkimiyet alanı içerisinde muamele görüyor oluşu insanlık adına düşündürücüdür. Oysaki BMDHS açık denizler ve uluslararası deniz yatağı ile ilgili kısımlarında bu alanların tüm insanlığın ortak kullanım alanı olduğundan bahsetmektedir. Şu anda üzerinde kesin bir egemenlik sınırı bulunmayan Arktik Okyanusu Açık Deniz Sahasının ve Uluslararası Deniz Yatağı'nın tüm insanlığın ortak malı olduğu unutulmamalıdır.

Nitekim Çin, Hindistan, G. Kore, Japonya gibi Arktik Okyanusu'na kıyısı olmayan ülkelerin, Arktik Konseyi içinde gözlemci ülke konumunu elde etmeleri önemlidir. Böylece bölgeyle ilgili alınacak kararlar ve uygulanacak politikalarda daha bağımsız ve tarafsız davranmak olası hale gelecektir. Ayrıca bu durum Rusya ve ABD gibi Arktik ülkelerini BMDHS çerçevesinde hareket etmeye zorlamaktadır. Rusya ve ABD Arktik'te güç mücadelesini bırakıp daha barışçıl politikalar izlemeli ve tüm insanlığın yararına olacak çalışmalar yapmaya yönelmelidirler. Çünkü bu bölge üzerinde gerçekleşecek herhangi bir değişimin ne derece yıkıcı sonuçları olacağı hakkında bilimsel kanıtlar bulunmaktadır.

Sonuç olarak, eksikleri dahi olsa BMDHS her açıdan Arktik Bölgesi ülkelerinin riayet etmesi gereken en önemli hukuk kaynağ 1 olarak başucunda tutulmalı ve özellikle Arktik Okyanusu'nun güvenliği için temel alınmaya devam edilmelidir.

\section{Extended Summary}

\section{Analysis of Arctic Security Policies from the Perspective of International Law: The Cases of Russia and the US}

In recent years, humanity has increased its capacity to search and find new things which are so significant for its protection and long-term survival. Today, one of the most important area for scientific research is accepted as Arctic Region. Because, Arctic keeps its natural richness under 
the ice where a new life waits to be explored. Different studies show that Arctic has a complex structure which should be analyzed with more than one perspective. Without complex technological and scientific developments, nobody would know that this structure is so important for human being. Thanks to the technology, Arctic has become so crucial in International Relations.

Arctic is a region covered with huge ice masses and located in the North Hemisphere of our planet. This area includes the Arctic Ocean and some territories which belongs to the neighboring countries around it. Russia, US, Canada, Denmark, Norway, Finland, Sweden and Iceland form the Arctic circle states, only five of these have a coastal to the Arctic Ocean. Arctic Ocean serves both big opportunities and risks for these countries. Even though these Arctic five agree on that the area should be under the sovereignty of the coastal states, most of the conflicts in oceanic areas available among them.

The global warming and the emerge of new type of threats increased the significance of Arctic Ocean and its security. Besides the neighboring countries of the Arctic Ocean which includes Russia, Canada, USA (Alaska), Denmark (Greenland) and Norway -All of them as known as the Arctic Five-, also non-coastal ones became the parts of the Arctic Policies. For instance, India as a coastal state has a great amount of population on its sea coast and, demanded to take an important position in Arctic Council. India claimed that if the sea level rises significantly because of the melting ice layers in Arctic, most of the its coastal cities will be damaged and population will suffer. In this respect, India wanted to be close to the Artic decisions as many other countries and applied to be a member state in Arctic Council and its membership was approved as an observer status. Problems arising from Arctic Region carry risks and have a potential effect to change ecological system. Thus, Arctic has taken a significant place in the agenda of many countries. However, we understand that the coastal states of the Arctic Region do not want to share the Arctic's benefits and consider the region as an area of interest. Therefore, they prefer to work compatible with the International Law to regulate practices and actions over the region. As we know that 1982 United Nation Convention on the Law of the Sea (UNCLOS) as an International Agreement provides legal base for the claims of coastal states. The coastal states which accepted and ratified the UNCLOS in Arctic Region, regulate their maritime delimitations and activities according to this document. 
Uluslararası Hukuk Çerçevesinden Arktik Güvenliği Politikalarının Analizi:

Rusya ve ABD Örneği

UNCLOS gives some rights and obligations to the signatory countries and the participant countries should obey the rules and regulations as ordered in the letter of agreement. As is known all the states that signed the agreement should be ratified, only after the ratification agreements enter into force. UNCLOS has been signed by all the Arctic countries but only US has not ratified it without ratification loses its many rights. Because of that US takes disadvantaged position among the Arctic five which claims additional rights and liberties on the Oceanic Area.

Particularly, the rivalry between Russian and American states are noteworthy. In the Arctic Ocean, Russia has enormous coastline when compared to the US. For this reason, the protection of the coastline, the boundaries of the continental shelf and the arrangements in the Exclusive Economic Zone (EEZ) have priority in the Arctic tasks of the Russia.

For instance; Russia claimed that the Lomonosov and Mendeleyev underwater ridges are the parts of the Russian Continental shelf and originated from the Russian continental plate. According to this argument, they applied to the UN for re-configuration of the boundaries related to the continental shelf of Russia. But the other Arctic states did not accept the Russian thesis and contrarily they defended that these ridges are passing under the North pole and originates from the North American Geological layer.

Many problems like militarization of the region, environmental pollution because of the drilling, protection of natural life and its residents are still on the agenda. But still, UNCLOS has a power to regulate this disharmony. And also like UNCLOS, The UN Declaration on the Rights of Indigenous Peoples provides an opportunity to take active role for all states that have been missing in practice till today.

As a conclusion, Russia and US consider the Arctic as their influence area. Economic and military importance of the region could not be ignored. But the Arctic states should focus on the region's unique nature and have to work for protection of these areas. Both states must use their full capacity to take important decisions about it. And it should not be forgotten that the UNCLOS will be serving for peace in Arctic.

\section{Kitaplar}

\section{Kaynakça}

Gardiner R. K. (2003). International Law. Harlow. Pearson Longman. 
Harris DJ. (2004). Cases and Materials on International Law, 6.th Edition. London. Thomson Sweet and Maxwell.

Hillier T. (1999). Principles of Public International Law, 2.nd Edition. Routledge Cavendish Publishing.

Köni H. (2016). Kaos-Batı Hâkimiyetinin Çöküşü, 2. Baskı. İstanbul. Wizart Edutainment.

Meray S. L. (1977). Uluslararası Hukuk ve Örgütler El Kitabı. Ankara. Ankara Üniversitesi Basımevi.

Pazarcı H. (2010). Uluslararası Hukuk, 9. Bask1. Ankara. Turhan Kitabevi.

Shaw M. N. (2008). International Law, 6.th Edition. Cambridge. Cambridge University Press.

Sur M. (2010). Uluslararası Hukukun Esasları, 4. Bask1. İstanbul. Beta Yayıncilik.

Young O. R. (1992). Arctic Politics, Conflict and Cooperation in the Circumpular North. Hanover. University Press of New England.

\section{e-Kitaplar}

Тишкова В. А. (Tişkova) (2016). Российская Арктика: коренные народы u промышленное освоение, Нестор-История. Москва. http://static.iea.ras.ru/books/Ros_arctica.pdf (20.01.2018).

\section{Makaleler}

Anderson J. (2016). The US Quietly Re-writes Arctic Policy. https://globalriskinsights.com/2016/11/23956/ (30.01.2018).

Axe D. (2015) Russia and America prep forces for Arctic war. http://blogs.reuters.com/great-debate/2015/10/04/russia-andamerica-prep-forces-for-arctic-war/ (28.11.2016).

Bittner J. (2016) To Whom Does The North Pole Belong? http://www.zeit.de/politik/ausland/2016-04/arctic-russia-americaconflict-zone (28.11.2016).

Browne M. A. (2006). The Law of the Sea Convention and U.S. Policy. http://www.gc.noaa.gov/documents/gcil_crs_2006_report.pdf (15.11.2017).

Buis A. (2016). First GRACE Follow-On Satellite Completes Construction. https:/grace.jpl.nasa.gov/news/86/first-grace-follow-on-satellitecompletes-construction/ (01.11.2017). 
Uluslararası Hukuk Çerçevesinden Arktik Güvenliği Politikalarının Analizi:

Rusya ve ABD Örneği

Conley H. A. (2015). America in the Arctic. https://www.csis.org/analysis/america-arctic (30.01.2018).

Cuthbertson L., Amores-Arrocha H., Malard L. A., Els N., Sattler B. and Pearce D. A., (2017). Characterisation of Arctic Bacterial Communities in the Air above Svalbard. http://www.mdpi.com/20797737/6/2/29/htm (01.11.2017).

Duyck S. "Drawing Lessons for Arctic Governance from the Antarctic Treaty System", http://www.arcticcentre.org/loader.aspx?id= f4817f72-7fde-4152-bd84-c4ec85f990f5 (31.01.2018).

Groves S. (2012). U.S. Accession to U.N. Convention on the Law of the Sea Unnecessary to Develop Oil and Gas Resources. http://www.heritage.org/report/us-accession-un-convention-the-lawthe-sea-unnecessary-develop-oil-and-gas-resources (10.11.2017).

Hank J. (2016). Why the US Needs to Ratify UNCLOS. https://thediplomat.com/2016/04/why-the-us-needs-to-ratify-unclos/ (11.11.2017).

Hirschfeld Davis J. (2015). Obama to Call for More Icebreakers in Arctic as U.S. Seeks Foothold. http://www.nytimes.com/2015/09/02/ us/politics/obama-to-call-for-more-icebreakers-in-arctic-as-us-seeksfoothold.html?_r=1 (28.11.2016).

Huebert R. (2009). United States Arctic Policy: The Reluctant Arctic Power. SPP Briefing Papers, Volume 2. Issue 2. https://www.policyschool.ca/wp-content/uploads/2016/03/ sppbriefing-huebertonline.pdf (30.01.2018).

Lefebvre B. (2017). Trump presses for Arctic offshore oil opening. https://www.politico.com/story/2017/04/27/trump-arctic-oiloffshore-237722 (24.01.2018).

Macalister T. (2011). Exhausted global oil supplies make Arctic the new hydrocarbon frontier. http://www.theguardian.com/environment/ 2011/jul/05/oil-supplies-arctic (5.11.2017).

Milazzo E. The Arctic: the role of indigenous peoples. https://accelfellowship.wordpress.com/the-arctic-the-role-ofindigenous-peoples/ (02.02.2018).

Mirasola C. (2015). Why the US Should Ratify UNCLOS: A View from the South and East China Seas. http://harvardnsj.org/2015/03/why-theus-should-ratify-unclos-a-view-from-the-south-and-east-china-seas/ (10.11.2017). 
Moore J. N. (2004). United States Adherence To The Law Of The Sea Convention A Compelling National Interest. http://www.virginia.edu/colp/pdf/house-testimony.pdf (15.11.2017).

Mortimer C. (2017) Russia is Building up It's Arctic Military Presence and Nato Should be Worried, Says New Report. http://www.independent.co.uk/news/world/europe/russia-arcticmilitary-presence-nato-worried-us-report-tensions-north-americaa7934741.html (24.01.2018).

Parfitt T. (2007). Russia plants flag on North Pole seabed. http://www.theguardian.com/world/2007/aug/02/russia.arctic (30.01.2018).

Patrick S. M. (2012). (Almost) Everyone Agrees: The U.S. Should Ratify the Law of the Sea Treaty. https://www.theatlantic.com/ international/archive/2012/06/-almost-everyone-agrees-the-usshould-ratify-the-law-of-the-sea-treaty/258301/ (11.11.2017).

Rabkin J. (2006) The Law of the Sea Treaty: A Bad Deal for America. Competitive Enterprise Institute Issue Analysis, No.3. http://www.cei.org/pdf/5352.pdf (10.11.2017).

Sorokin I. (2015). The UN Convention on the Law of the Sea: Why the U.S. Hasn't Ratified It and Where It Stands Today. http://berkeleytravaux.com/un-convention-law-sea-u-s-hasntratified-stands-today/ (18.11.2016).

Virtanen, V. (2013) The Arctic in World Politics. The United States, Russia, and China in the Arctic - implications for Finland. http://projects.iq.harvard.edu/files/fellows/files/virtanen.pdf (28.11.2017).

Watson P. (2017) A Melting Arctic Could Spark a New Cold War. http://time.com/4773238/russia-cold-war-united-states-artic-donaldtrump-barack-obama-vladimir-putin/ (27.01.2018).

Алиферова А. В. (Aliferova) (2012). История Освоения Арктики, Россия в Арктике XXI век: среда обитания, общество, освоение, Материалы I Всероссийской молодёжной конференции 14-15 июня 2012 г. Томского политехнического университета. Томск. 2012. (ss.6-8). http://www.lib.tpu.ru/fulltext/c/2012/C74/C74.pdf (23.11.2017).

Виноградов Е. (Vinogradov) (2013) Эксперты против добычи нефти и газа в Арктике. http://inosmi.ru/world/20130419/208226451.html (28.09.2016). 
Uluslararası Hukuk Çerçevesinden Arktik Güvenliği Politikalarının Analizi:

Rusya ve ABD Örneği

Кай И. и Филатова И. (Kai ve Filatova) (2013). Борьба за Арктику: видна лишь вершина айсберга? http://inosmi.ru/russia/ 20131107/214529054.html (27.09.2016).

Ковалев А.А. (Kovalev) (2013) Международно-Правовой Режим Арктики И Интереси России, Ред. И. С. Иванова, Арктический Регион Проблемы Международного Сотрудничества том 1, Аспект Пресс. Москва. (ss. 25-41). http://russiancouncil.ru/ common/upload/Arctic\%20Anthology\%20V ol\%201-1.pdf (10.01.2018).

Конышев В. и Сергунин А. (Konişev ve Sergunin) (2011). Арктическое Направление Внешней Политики России: Проблемь и Перспективы. Обозревател-Observer, 3/2011. https://www.hse.ru/pubs/share/direct/document/75054638 (26.09.2016).

Матвеевич П. Л. (Matveyeviç) (2011). Международно-nравовые проблемь раздела экономических пространств Арктики. https://regnum.ru/news/1449911.html (26.01.2018).

Половинкин В. Н. и Фомичев А. Б. (Polovinkin ve Fomiçev) (2013). Значение Северного И Арктического Регионов В Новых Геополитических И Геоэкономических Условиях Арктика. экология и экономика № 3 (11). http://arcticaac.ru/docs/3\%2811\%29/058_063_ARKTIKA_3\%2811\%29_09_201 3.pdf (12.11.2017).

Пушкарев М.C. (Puşkaryev) (2012) Состояние и Перспективы Освоения Месторождений Нефти и Газа Арктического Шельфа. Россия в Арктике XXI век: среда обитания, общество, освоение, Материалы I Всероссийской молодёжной конференции 14-15 июня 2012 г. Томского политехнического университета. Томск. (ss. 29-31). http://www.lib.tpu.ru/fulltext/c/2012/C74/C74.pdf, (23.11.2017).

Рагаускас P. (Ragauskas) (2011). Приоритеть и политика России в арктическом регионе. http://inosmi.ru/arctica/20110427/ 168837531.html, (28.09.2016). 


\section{Yazarı Belli Olmayan Makaleler}

Arctic Regions And Its Concerns, Threats And Potential Challenges.http://ec.europa.eu/echo/files/civil_protection/civil/prote/ pdfdocs/pretear_final_report_en.pdf, (s.10) (14.11.2017).

Arctic Sunrise case: Russia ordered to pay damages. http://www.bbc.com/news/world-europe-34045493 (11.11.2017).

China, Japan, South Korea to Hold Talks on Arctic Region http://www.scmp.com/news/china/diplomacy/defence/article/193838 2/china-japan-south-korea-hold-talks-arctic-region (25.11.2016).

Thawing Permafrost: A Slow, Giant Carbon Release. https://insideclimatenews.org/content/thawing-permafrost-slowgiant-carbon-release (09.11.2017).

The Arctic Environment. https://www.nwf.org/ /media/PDFs/ Be\%20Out\%20There/Schoolyard\%20Habitats/ArcticEnvironment. pdf, (s.1) (14.11.2017).

The Melting North. http://www.economist.com/node/21556798 (11.11.2017).

The Polar Regions. http://www.educapoles.org/assets/uploads/ teaching_dossiers_files/dp_cze_01_en.pdf, (s.2), (14.11.2017).

The United Nations Convention on the Law of the Sea (A historical perspective). http://www.un.org/Depts/los/convention_agreements/ convention_historical_perspective.htm\#Third Conference (14.11.2017).

Американские ледоколь с ракетами на борту могут подорвать сотрудничество в Арктике. http://mixednews.ru/archives/120522 (05.11.2017).

Государственная политика в Арктике: проблемь и перспективы. http://www.arctic-info.ru/FederalMonitoringMedia/21-052012/gosydarstvennaa-politika-v-arktike--problemi-i-perspektivi-monitoring-federal_nih-smi--14-20-maa-20/ (24.09.2016) .

Зачем России Арктика. http://www.lgz.ru/article/-14-6593-12-042017/zachem-rossii-arktika/ (07.11.2017)

HАTO: экспансия в Арктику. http://odynokiy.livejournal.com/337474.html (06.11.2017).

Путин поручил правительству "защитить" интересы России в Арктике. https://www.unian.net/world/1849664-putin-poruchilpravitelstvu-zaschitit-interesyi-rossii-v-arktike.html (5.11.2017). 
Uluslararası Hukuk Çerçevesinden Arktik Güvenliği Politikalarının Analizi:

Rusya ve ABD Örneği

\section{Web Sitesi}

http://government.ru/info/18359/, (25.09.2017)

http://government.ru/info/18360/, (02.02.2018)

http://kremlin.ru/acts/bank/42117/page/1, (02.02.2018)

http://kremlin.ru/events/president/news/50060, (04.01.2018)

http://library.narfu.ru/sites/arctic/rus/info/gosud politika_v arktike/Pages/p азграничение-континентального-шельфа.aspx , (27.01.2018)

http://static.kremlin.ru/media/events/files/ru/uAFi5nvux2twaqjftS5yrIZUVT Jan77L.pdf, (02.02.2018)

http://www.arctic-council.org/index.php/en/ (25.11.2017)

http://www.oceanlaw.org/downloads/arctic/Ilulissat_Declaration.pdf

http://www.theguardian.com/world/2011/jul/06/us-russia-political-tensionsarctic, (17.06.2015)

http://www.un.org/depts/los/convention_agreements/texts/unclos/unclos_e. pdf, (24.11.2016)

http://www.un.org/esa/socdev/unpfii/documents/DRIPS_en.pdf, (21.01.2018)

http://www.unicankara.org.tr/doc_pdf/denizhukuku.pdf (26.01.2018)

http://www.wikiwand.com/en/Ilulissat_Declaration (30.10.2017)

https://directory.eoportal.org/web/eoportal/satellite-missions/g/grace-fo, (09.11.2017)

https://www.itlos.org/fileadmin/itlos/documents/cases/case_no.22/published /C22_Order_221113.pdf, (s.252) (11.11.2017)

\section{Raporlar}

Heininen L., Sergunin A., Yarovoy G., (2014). Russian Strategies in the Arctic: Avoiding A New Cold War, Valdai Discussion Club Report. http://www.uarctic.org/media/857300/arctic_eng.pdf, (17.06.2015)

O'Rourke R. (2015) Changes in the Arctic: Background and Issues for Congress. Congressional Research Service Report. https://www.fas.org/sgp/crs/misc/R41153.pdf, (17.06.2015)

Report to Congress on Strategy to Protect United States National Security Interests in the Arctic Region (2016). Department of Defense Report. https://www.defense.gov/Portals/1/Documents/pubs/2016-ArcticStrategy-UNCLAS-cleared-for-release.pdf, (01.02.2018) 
Хейнинен Л., Сергунин А. и Яровой Г. (Heininen, Sergunin ve Yaravoy) (2014) Политика России В Арктике: Как Избежать Новой Холодной Войны, Доклад грантополучателей Международного дискуссионного клуба «Валдай». https://narfu.ru/aan/ Encyclopedia_Arctic/arctic_rus.pdf, (17.09.2016). 